\title{
Phanerozoic denudation across the Kola Peninsula, Northwest Russia: implications for long-term stability of Precambrian shield margins
}

\author{
Adrian Malcolm Hall' \\ ${ }^{1}$ Department of Physical Geography, Stockholm University, S-10691 Stockholm, Sweden. \\ E-mail corresponding author (Adrian Malcom Hall): adrian.hall@natgeo.su.se
}

Contrasting views exist on the stability of the Earth's shield regions over the last $1 \mathrm{Ga}$ that have major implications for reconstructing erosion patterns on shields and the supply of sediment to intra-cratonic and marginal basins. This paper explores Phanerozoic denudation rates and patterns on the northern part of the Fennoscandian Shield in the Kola Peninsula, Northwest Russia. This shield region was intruded by magmatic rocks of the Kola Alkaline Province (KAP) in the Devonian and Early Carboniferous. The KAP comprises a varied suite of alkali-ultramafic plutonic and hypabyssal intrusions, diatremes and dykes that was emplaced at various depths in the crust and allows assessment of depths and rates of erosion during and since the KAP magmatic episode. Further evidence of long-term denudation is provided by Mesoproterozoic and Neoproterozoic cover rocks found around the margins of the Kola Peninsula and in the White Sea. The burial and exhumation history is compared to available Apatite Fission Track (AFT) data for the Kola Peninsula and adjacent areas. Post-Devonian denudation rates on the shield rocks of the Kola Peninsula have varied in space and time. Around the periphery of the Kola Peninsula, low long-term denudation of shield rocks is indicated by the survival of Riphean cover rocks and Late Devonian lavas, kimberlite crater facies and near-surface emplacement of dykes. In contrast, in the main belts of KAP intrusions, 4-6 km of rock was removed in response to doming between 460 and $360 \mathrm{Ma}$. Deep denudation is indicated by the emplacement depths of alkaline intrusions and Phoscorite-Carbonatite pipes (PCPs). Erosion on the Kola Peninsula since $360 \mathrm{Ma}$ has been far more limited. Extensive, shallow, late-stage magmatism associated with PCPs, dykes and the large alkaline intrusions in the KAP indicates that erosion depths nowhere exceeded $2 \mathrm{~km}$. PostDevonian denudation has removed $<1 \mathrm{~km}$ of rock from the margins of the Kola Peninsula and from the backslope of the Saariselkä-Karelia scarp in northern Finland. AFT data point to an important phase of erosion in the early Mesozoic but depths of unroofing of 3-5 km based on AFT cooling ages for this later phase are in conflict with the evidence of lesser erosion provided by the late-stage KAP intrusions and also require unrealistic depths of former Devonian to Triassic cover rocks. Mean denudation rates were greatest (up to $40 \mathrm{~m} / \mathrm{Myr}$ ) during the KAP magmatic phase. Post-Devonian rates across the Kola Peninsula and adjacent shield areas were much lower $(<3-6 \mathrm{~m} / \mathrm{Myr})$ and are compatible with low long-term denudation rates for other cratons. Further resolution of long-term denudation patterns and rates on the Kola Peninsula requires the application of low-temperature thermochronometry, detailed examination of the regional geomorphology and firmer dating of ancient weathering episodes.

Keywords: Kola, passive margin, denudation rates, Precambrian, shield

Received 15. February 2015 / Accepted 13. June 2015 / Published online 11. September 2015

\section{Introduction}

Contrasting views exist on the stability of the Earth's shields over the last $1 \mathrm{Ga}$. A long-established view is that, once assembled, shields develop under a cratonic regime (Fairbridge \& Finkl, 1980) with very slow denudation, a consequence of low rates of uplift, persistent planation of relief and shut-down of erosion for long periods dur- ing repeated episodes of shallow-marine transgression and burial. A more recent and sharply contrasting view, grounded firmly in apatite fission track (AFT) thermochronology (Osadetz et al., 2002; Belton et al., 2004; Kohn et al., 2009), is that even shield interiors are tectonically dynamic, with $\mathrm{km}$-scale phases of burial and exhumation that require large vertical movements of deep-rooted continental crust and long periods of erosion during the Phanerozoic. Resolving this debate is important not only

Hall, A.M. 2015: Phanerozoic denudation across the Kola Peninsula, Northwest Russia: implications for long-term stability of Precambrian shield margins. Norwegian Journal of Geology 95, 153-169. http://dx.doi.org/10.17850/njg95-2-02.

(c) Copyright the author.

This work is licensed under a Creative Commons Attribution 4.0 International License. 
for assessing the stability of shields but also for reconstructing erosion histories on shields and quantifying sediment supply to intra-cratonic and marginal basins.

Yet long-term (1-1000 Myr) denudation rates on shields remain poorly constrained, largely because erosion removes evidence of its progress. This problem is most acute for the shields of the Northern Hemisphere. Here, Late Cenozoic glacial erosion has generally acted to remove correlative cover rocks and regolith and to strip bare the Precambrian basement. Although glacial erosion has frequently not erased major preglacial landforms, such as erosion surfaces of regional extent (Ebert et al., 2011), only a few attempts have been made to use preglacial landforms and deep weathering to reconstruct relief development and erosion patterns on northern shields before the Pleistocene (Lidmar-Bergström, 1996, 1999; André et al., 2001; Lidmar-Bergström et al., 2007, 2012). A further difficulty is that Phanerozoic igneous rocks that might provide markers for long-term denudation are sparse on both the Canadian and the Fennoscandian shields (Stasiuk et al., 2006; Wolfe et al., 2012). Under these circumstances, most estimates of the depth, rate and timing of long-term denudation on glaciated shields rely heavily on AFT studies of regional thermochronology (Hendriks \& Andriessen, 2002; Murrell \& Andriessen, 2004; Ault et al., 2009). Yet interpretation of AFT data is strongly model dependent and requires integration with other regional geological data (Gunnell, 2000; Hall \& Bishop, 2002).

This paper examines integrated Phanerozoic denudation rates and patterns on the northern part of the Fennoscandian Shield in the Kola Peninsula, Northwest Russia (Fig. 1). Two opposing views exist on the long-term denudation of the central Kola Peninsula: (i) that erosion since $\sim 2.5 \mathrm{Ga}$ has been insignificant (Evzerov, 2001) or that (ii) $\mathrm{km}$-scale erosion has occurred since $460 \mathrm{Ma}$ (Arzamastsev et al., 2000). The northeastern part of the Fennoscandian Shield comprises Archaean and Palaeoproterozoic igneous and crystalline supracrustal rocks (Fig. 2). This Archaean-Palaeoproterozoic basement was intruded in the Devonian and Early Carboniferous by the magmatic rocks of the Kola Alkaline Province (KAP), a varied suite of alkali-ultramafic plutonic and hypabyssal intrusions, diatremes and dykes. This review evaluates evidence of

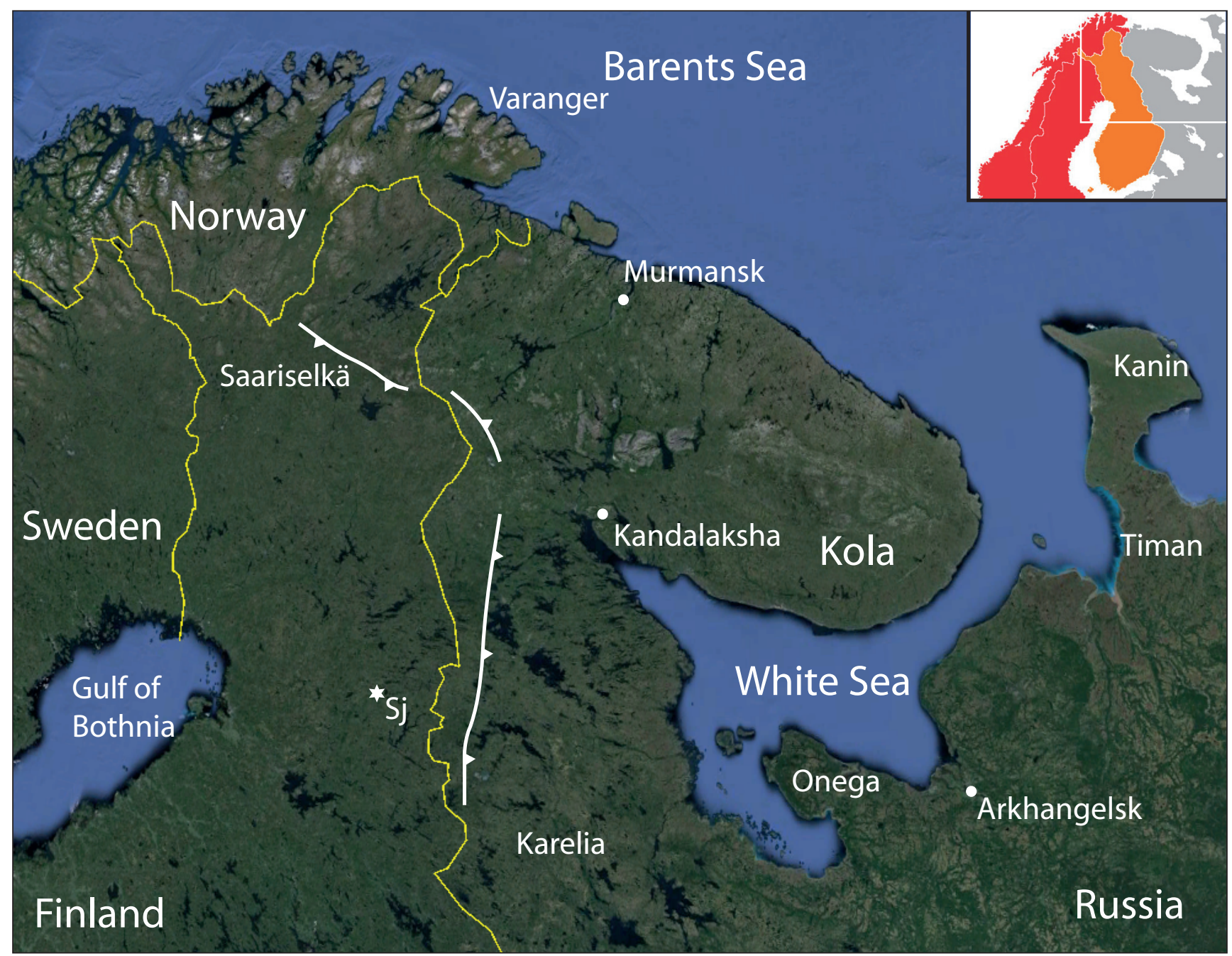

Figure 1. Location of the Kola Peninsula and adjacent areas. Inset shows the main study area. Abbreviation: Sj - Saarijärvi impact crater. 


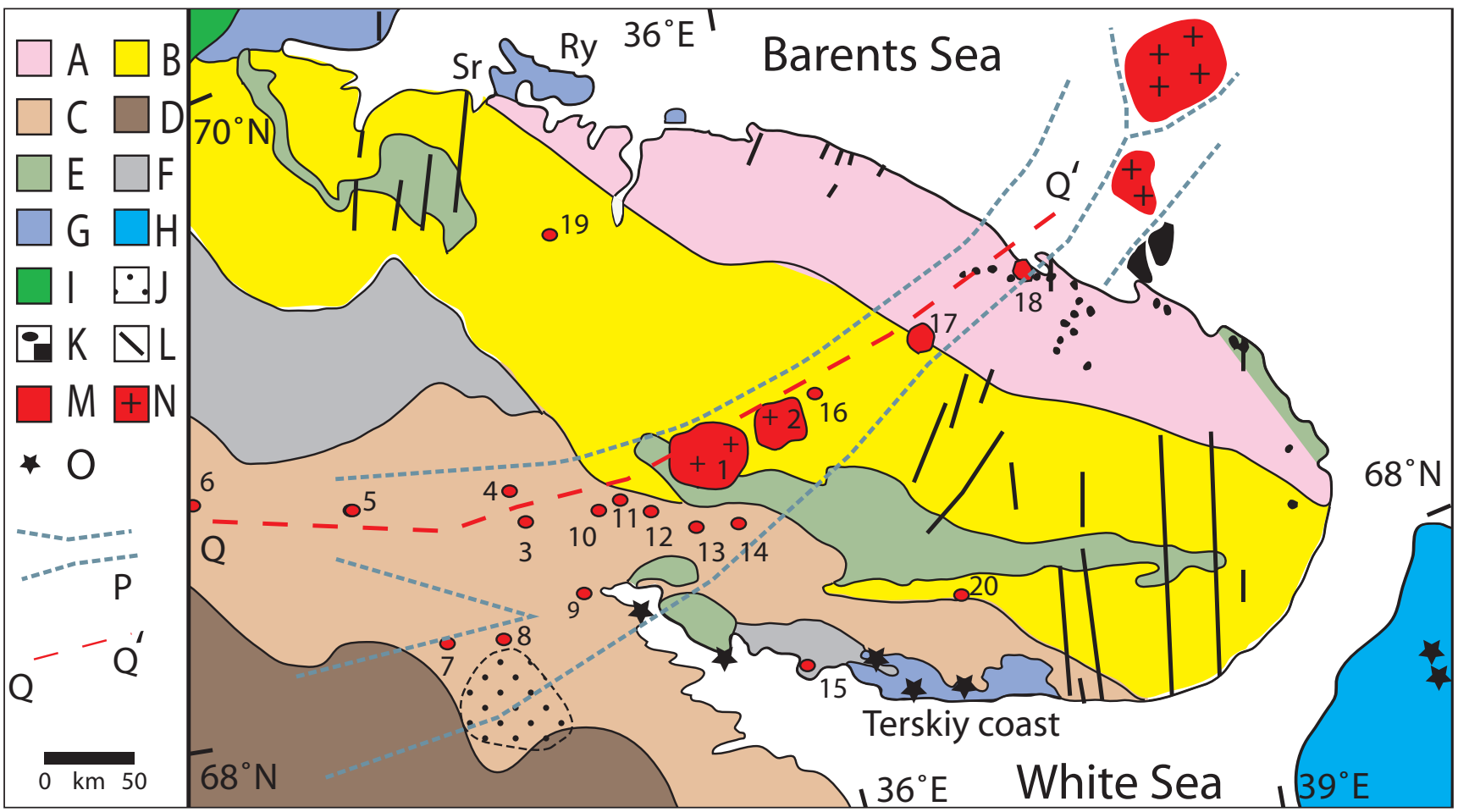

Figure 2. Simplified geology of the Kola Peninsula and adjacent parts of Russia and Finland. 'A' - Murmansk Terrane. 'B' - Central Kola Composite Terrane. 'C'-Belomorian Terrane. 'D' - Karelian Province. 'E' - Palaeoproterozoic rift basins. 'F' - Lapland Granulite Belt. 'G' - Riphean sedimentary rocks. 'H' - Vendian sedimentary rocks. 'I' - Caledonides. 'J' - Zone of Devonian diamondiferous dykes (after Terekhov et al., 2012). 'K' - Devonian lavas. ' $L$ ' - Phanerozoic dykes. ' $M$ '- Phoscorite-Carbonatite pipes. ' $N$ ' - Nepheline syenites. 'O'- Kimberlite. 'P'- Kontozero Graben boundaries (after Kramm et al., 1993). 'Q' - Line of section Q-Q' for Figs. 8 \& 9. KAP intrusions: 1 - Khibiny. 2 - Lovozero. 3 - Niva. 4 - Mavraguba. 5 - Kovdor. 6 Sokli. 7 - Sallanlatva. 8 - Vuoriyarvi. 9 - Kandaguba. 10 - Afrikanda. 11 - Lesnaya Varaka. 12 - Ozernaya Varaka. 13 - Salmagora. 14 - Ingozero. 15 - Turiy Mys. 16 - Kurga. 17 - Kontozero. 18 - Ivanovka. 19 - Seblyavr. 20 - Pesochny. Abbreviations: Ry - Rybachiy, Sr - Sredniy.

emplacement depths for KAP intrusions and assesses depths of post-Devonian erosion of basement and cover across the Kola region. Further constraints on long-term denudation are provided by Mesoproterozoic and Neoproterozoic cover rocks found around the margins of the Kola Peninsula and in the White Sea. The burial and exhumation history is compared to available AFT data for the Kola Peninsula and adjacent areas. The revealed denudation patterns show that whilst rates of long-term, average denudation are comparable to those determined for other shields, erosion across Kola has been spatially and temporally variable over the last $460 \mathrm{Myr}$.

\section{Geology}

The Kola Peninsula occupies a pivotal location at the northeastern edge of the Norwegian passive margin, the southern shore of the Barents Sea and the northern edge of the Fennoscandian Shield (Fig. 1). The Baltic Shield is subdivided into several separate domains of which the oldest is the mainly Archaean Kola-Karelian domain which, in turn, is split into the Murmansk, central Kola and Belomorian terranes (Fig. 2). The Archaean basement consists mainly of gneiss, schists, anorthosite, basic intrusive rocks and granites. In the Palaeoprotero- zoic at 2.5-2.1 Ga, extensive rift systems were formed. Fennoscandia experienced drifting and separation of Archaean cratons by newly formed oceans at 2.1- 2.04 $\mathrm{Ga}$. The ensuing main Palaeoproterozoic orogenic phase produced the Lapland-Kola orogen $(1.94-1.86 \mathrm{Ga})$ and the composite Svecofennian orogen (1.92-1.79 Ga) (Daly et al., 2006; Lahtinen et al., 2008). The structural framework of the northern Fennoscandian Shield was assembled by $\sim 1.5 \mathrm{Ga}$, but partly reactivated during the Sveconorwegian (1.2-0.85 Ga) and Caledonian (0.5-0.4 Ma) orogenies (Claesson et al., 2000).

Neoproterozoic sedimentary rocks occur around the margins of the Kola Peninsula (Fig. 3). In the Russian literature, these rocks continue to be referred to as Late Riphean (950-635 Ma) and Vendian (635-541 $\mathrm{Ma})$ in age, as the recommendations of the International Commission on Stratigraphy have been slow to be adopted. That usage is generally maintained in this paper for ease of comparison. The total Neoproterozoic thickness in the Kola-Kanin Monocline off the north Kola coast is $6 \mathrm{~km}$ (Fig. 4) and is mainly Tonian to Cryogenian in age. In the northern Kola Peninsula and offshore, platform sedimentary rocks rest unconformably on basement on the Sredniy Peninsula (Siedlecka et al., 1995a; Mitrofanov et al., 2004), and are separated from basinal sediments on the Rybachiy Peninsula (Fig. 


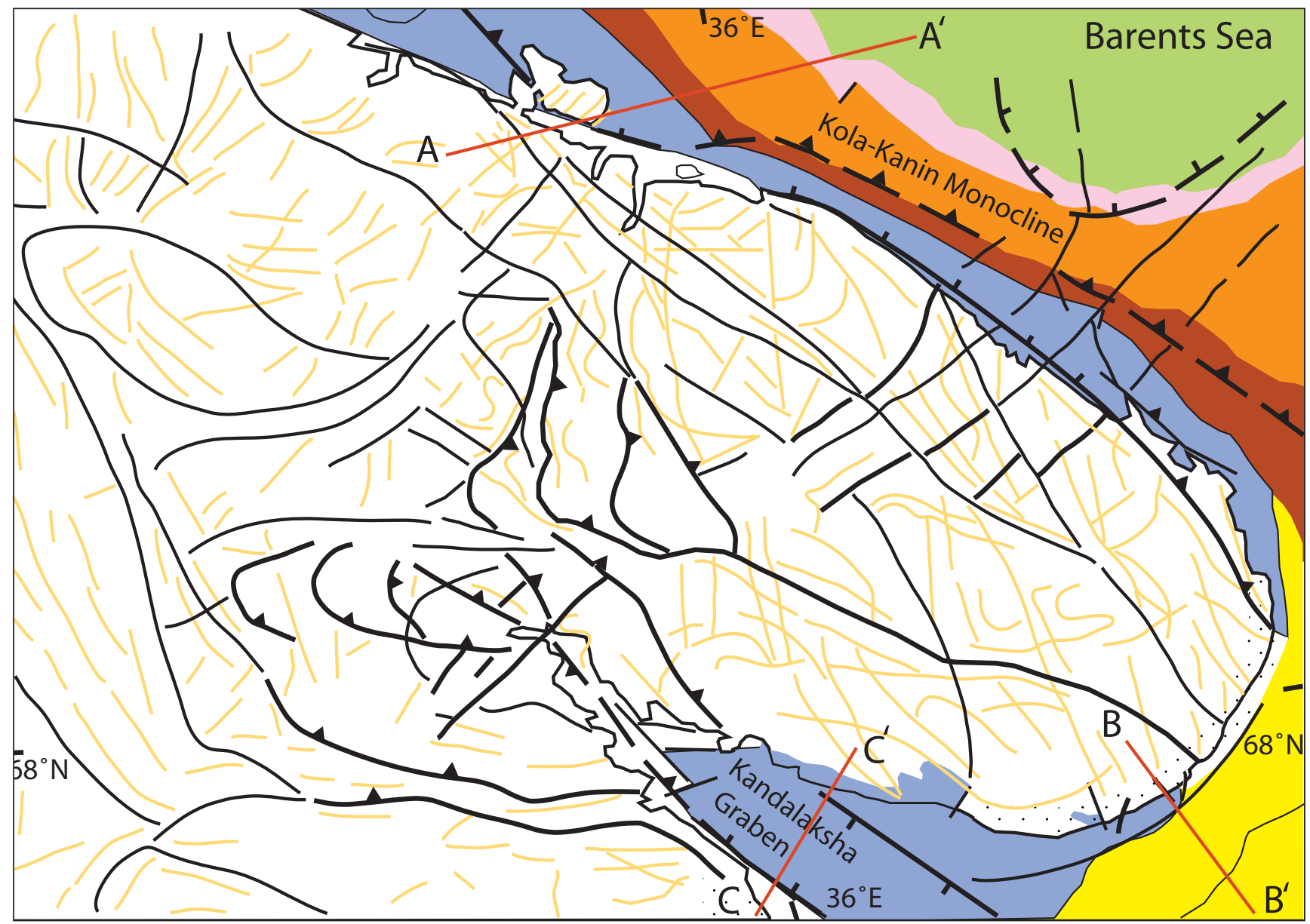

Figure 3. Geology of the southern Barents and White seas and the major structural elements controlling the localisation of Devonian alkaline and tholeiitic igneous rocks on the Kola Peninsula and in Karelia. 1 - Basement rocks. 2 - Late Riphean sedimentary rocks. 3 - Vendian sedimentary rocks. 4 - Palaeozoic sedimentary rocks, excluding those of Permian age. 5 - Permo-Triassic sediments. 6. Jurassic sediments. 7 - Cretaceous sediments. 8 - Sub-Vendian Peneplain. Modified from Roberts et al. (1997). 'A'- Major inclined fault. 'B' - Major vertical fault. 'C' - Other major structures. 'D' - Minor structures. Modified after Terekhov et al. (2012). A-A'-geological section in Figure 4. B-B', C-C' - geological sections in Figure 5 .

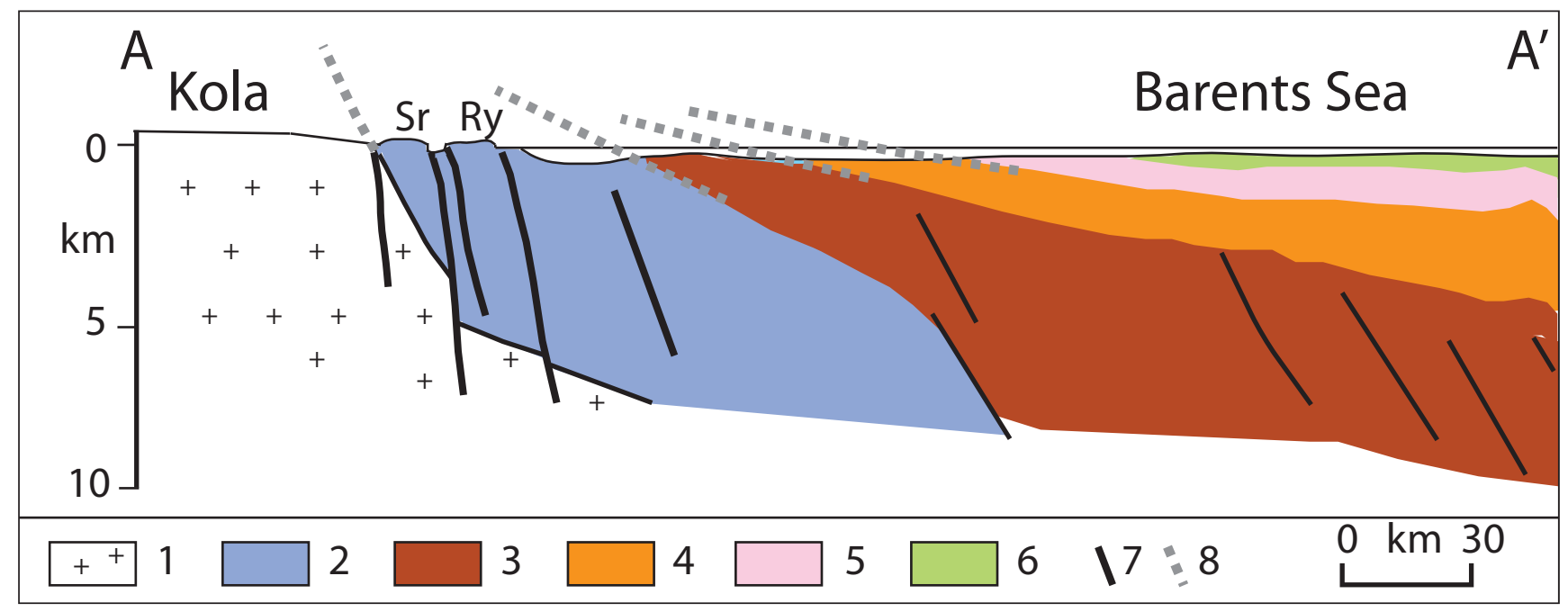

Figure 4. Schematic geological section of the Kola-Kanin Monocline. 1 - Basement. 2 - Late Riphean. 3 - Palaeozoic, excluding Permian. 4 Permo-Triassic. 5 - Jurassic. 6 - Cretaceous. 7 - Fault. 8 - Projected unconformity. Line of section shown on Fig. 3. Modified after Ivanova (2001). 
2) by a major fault zone (Roberts, 1995; Olovyanishnikov et al., 1998). In the White Sea, Tonian to Ediacaran rocks have a stratigraphic thickness of up to $8 \mathrm{~km}$ within halfgrabens separated by intervening basement ridges (Baluev et al., 2009). The Vendian Complex in the southeastern White Sea is mainly of Ediacaran age, up to $550 \mathrm{~m}$ thick, and fills grabens and deep troughs developed in basement and Late Riphean sedimentary rocks (Fig. 5; Grazhdankin, 2003).

The Kola Alkaline Province (KAP) (Fig. 2) is related to Devonian continental rifting (Beard et al., 1998). Ultrabasic and alkaline complexes, along with numerous dykes and pipes, were intruded in the Kola Peninsula and on the Barents shelf during the Middle Palaeozoic (Kogarko et al., 1995). The central alkaline complexes, including Khibiny and Lovozero, form a NESW-trending belt, associated with the Kontozero Graben (Fig. 2), while the alkaline complexes of Sokli (Finland), Kovdor, Kandagubskiy and Turiy Mys form an E-Wtrending belt spatially associated with the Kandalaksha deep fracture zone, an older structure initiated in the Neoproterozoic (Fig. 3; Vartiainen \& Paarma, 1979). Igneous activity may have started as early as $460 \mathrm{Ma}$ and large alkaline lava xenoliths at Lovozero and Kontozero record an early phase of volcanic activity at $\sim 404 \mathrm{Ma}$ before the injection of the large alkaline intrusions at 380-360 Ma (Arzamastsev et al., 2010, 2013). A swarm of dolerite dykes on the Barents Sea coast has provided ages clustered around $370 \mathrm{Ma}$ and indicate that dyke injection and lava eruption here belong to the main magmatic phase (Beckinsale et al., 1975; Kramm et al., 1993; Guise \& Roberts, 2002). These coastal dykes, however, originally fed basaltic lava fields and relate to igneous centres offshore rather than to the major alkaline igneous centres on the Kola Peninsula (Fig. 3; Terekhov et al., 2012). Dykes near Kandalaksha are also dated to $~ 380$ $\mathrm{Ma}$ (Claesson et al., 2000) and are considered as eruptive channels for volcanic fields later removed by erosion (Bulakh \& Ivanikov, 1984). Explosion pipes, including kimberlites on the Terskiy coast, have provided similar $\mathrm{K}-\mathrm{Ar}$ ages of 382-365 Ma (Beard et al., 1998).

Multiple phases of extension and rifting have been recognised in the southern Barents Sea from the Carboniferous, in Permo-Triassic time and also in the Late Jurassic-Early Cretaceous, with Late Cretaceous-Early Tertiary basin inversion (O'Leary et al., 2004; Shipilov, 2015). The northward-dipping wedge of Palaeozoic to Triassic sedimentary rocks in the Kola-Kanin Monocline off the Murmansk Coast reaches a total thickness of $5 \mathrm{~km}$ (Fig. 4; Ivanova, 2001) but much of this detritus was sourced from the Urals (Artemieva, 2003). Extension of sedimentary cover over the Kola Peninsula in the Late Devonian and Late Carboniferous, but not later, is depicted on palaeographic maps of the European Platform (Nikishin et al., 1996). Reactivation of major faults is recognised along the northern Norwegian Atlantic margin at intervals through the Devonian to Permian (Roberts \& Lip- pard, 2005; Davids et al., 2013) and extending into the Late Cenozoic (Eidvin et al., 2014; Knies et al., 2014). Cenozoic denudation on the Kola Peninsula is estimated at $<0.5 \mathrm{~km}$ based on vitrinite reflectance, sandstone diagenesis and shale compaction indices on the Barents shelf (Henriksen et al., 2011a). In northern Fennoscandia, the main topographic feature of the shield today is a major scarp, the Saariselkä-Karelia escarpment (Fig. 1), that separates the uplifted and tilted backslope of northern Finland from the foreland of northern Karelia and the Kola Peninsula.

\section{Estimating long-term denudation on the Kola Peninsula}

This section examines how different geological indicators may constrain depths of Phanerozoic denudation on the Kola Peninsula.

\section{Neoproterozoic sedimentary rocks}

Riphean sedimentary rocks occur at present only around the fringes of the Kola Peninsula (Fig. 3). On the Rybachiy Peninsula (Fig. 1), thick, very coarse-grained, sandstone turbidites are interbedded with conglomerates and a basal olistostrome-breccia (Siedlecka et al., 1995b; Mitrofanov et al., 2004). In the eastern Kola Peninsula, the Riphean sedimentary rocks are much finer grained, with thick siltstone units (Baluev et al., 2009), and were originally deposited in half-grabens within mountainous terrain (O'Leary et al., 2004). Along the north coast of the Kola Peninsula, Riphean rocks have been faulted and laterally displaced along the Karpinsky Lineament (Fig. 3; Siedlecka, 1995; Roberts et al., 1997), a long established feature that marks the hinge zone between the southern Barents Sea basin and the exposed shield.

In the immediate vicinity of Riphean cover rocks, erosion of basement has been negligible. In contrast, away from these cover rocks, extrapolation onto the Kola Peninsula of the trends of the irregular, sub-Riphean unconformities in both the southern Barents Sea (Mitrofanov et al., 2004) and the White Sea (Zhuravlev \& Shipilov, 2008) indicate many kilometres of postRiphean denudation (Figs. 4 \& 5). Much of this erosion occurred during the interval between the end of Riphean sedimentation after $630 \mathrm{Ma}$ (Gorokhov et al., 2002) and the onset of a Late Vendian depositional phase at $\sim 555 \mathrm{Ma}$ (Martin et al., 2000), a period of uplift linked to the intrusion of the Rybachiy dolerite dyke swarm at 600-540 Ma (Arzamastsev et al., 2010). The absence of Riphean and Vendian rocks either below Early Devonian lavas or as roof pendants in the main alkaline intrusions at Khibiny and Lovozero (Arzamastsev et al., 2013) indicates removal of any Riphean or Vendian cover from central Kola by 410 Ma. Around Arkhangelsk and 


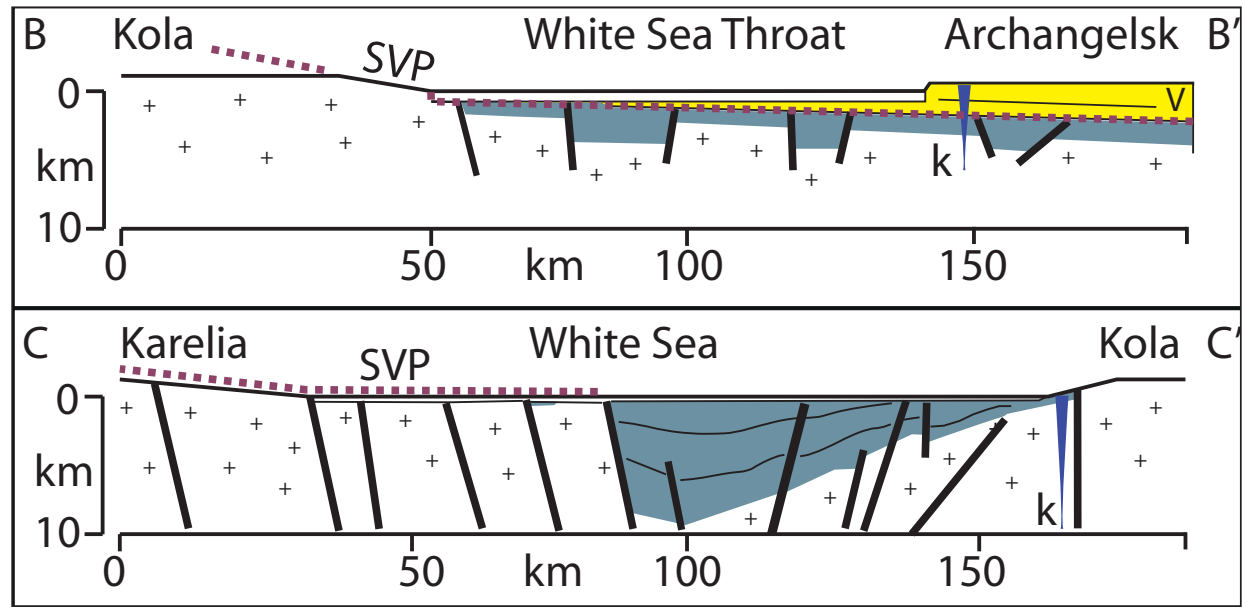

Figure 5. Schematic geological sections across the White Sea. Lines of section shown on Fig. 3. Key as in Fig. 4. Modified after Zhuravlev \& Shipilov (2007). SVP - Sub-Vendian Peneplain.

in northern Karelia, the sub-Late Vendian unconformity is a peneplain cut across both Archaean basement and Riphean half-grabens (Figs. $3 \& 5$ ). The peneplain is overlain by horizontally-dipping sandstones and mudstones (Grazhdankin, 2003). Along the easternmost fringe of the Kola Peninsula, the sub-Vendian peneplain (SVP) is tilted and occurs as a gently inclined ramp rising to $\sim 200 \mathrm{~m}$ a.s.l. where it is truncated by a younger, subhorizontal erosion surface (Fig. 5). The ramp has an eastward gradient of $8-14 \mathrm{~m} / \mathrm{km}$, indicating $\mathrm{km}$-scale, post-Vendian denudation in the eastern Kola Peninsula. The sub-Vendian peneplain is a widespread feature of the Russian Platform and of the Fennoscandian Shield around the Baltic Sea (Paulamäki \& Kuivamäki, 2006). The SVP may have extended across the Kola Peninsula but evidence that Neoproterozoic alkaline ultramafic magmatism was underway by $600 \mathrm{Ma}$ (Downes et al., 2005) suggests that Kola may have retained significant relief even in this phase of regional planation. The SVP forms inherited relief on the present shield surface south of Onega Bay (Fig. 3) but here it has been uplifted to the south, disrupted by block movements and stripped of Vendian sedimentary rocks (Grazhdankin, 2003).

\section{Devonian magmatism}

Each of the main manifestations of Devonian magmatism is examined below for evidence of its emplacement depth in order to derive estimates of later denudation. Interpretation of this evidence is generally difficult due to the complexity of the processes of emplacement and mineralisation during multiple phases of magmatic activity. In general, the most useful indicators of post-Devonian erosion are near-surface rocks formed in the later stages of KAP magmatism.
Major alkaline volcanic centres and intrusions

The major alkaline magmatic centres of Khibiny and Lovozero have a complex history that spans the period from 387 to $347 \mathrm{Ma}$ (Arzamastsev \& Petrovsky, 2012). Three main phases of activity can be recognised (Kogarko, 1987; Arzamastsev et al., 2013): dyke intrusion and volcanism and development of large calderas, followed by syenite intrusion within a framework of ring faults, and ending with Phoscorite-Carbonatite pipe (PCP) and dyke intrusion, and hydrothermal activity (Fig. 6). The Kontozero complex (Fig. 1), dating from $380 \pm 8 \mathrm{Ma}$ (Arzamastsev \& Petrovsky, 2012), consists of diverse plutonic and volcanic, alkaline, ultramafic and carbonatitic rocks, up to $2.6 \mathrm{~km}$ thick (Arzamastsev \& Petrovsky, 2012), that fill a caldera-like depression averaging about $8 \mathrm{~km}$ in diameter in the central part of the Kola Peninsula (MacBride, 2005). The Ivanovka volcanic-plutonic complex, of similar age, on the Barents Sea coast remains largely buried. Remnants of volcanic rocks are found up to $18 \mathrm{~km}$ from the centre and rest on Archaean granites, Riphean sedimentary rocks, and Riphean dolerites (Arzamastsev \& Petrovsky, 2012). Gravimetric surveys indicate that a second alkaline centre exists at depth nearby (Arzamastsev et al., 2000). The major volcanic centres are estimated to have produced large volumes of alkaline lavas and plateau basalts during the magmatic phase, with a speculative original thickness of $2 \mathrm{~km}$ over the Kola Peninsula (Downes et al., 2005). Distal remnants of this cover may be represented by Late Devonian tholeiitic lavas and tuffs on the Kanin Peninsula and in northern Timan (Mahotkin et al., 2000).

Lavas representing early ultrabasic and alkaline volcanic activity occur as roof rocks at Lovozero and as numerous xenoliths at Khibiny (Arzamastsev \& Petrovsky, 2012). Preservation of these rocks within and not outside ring faults is a result of subsidence and burial. At Ivanovka, in contrast, basaltic lavas are distant from the igneous 


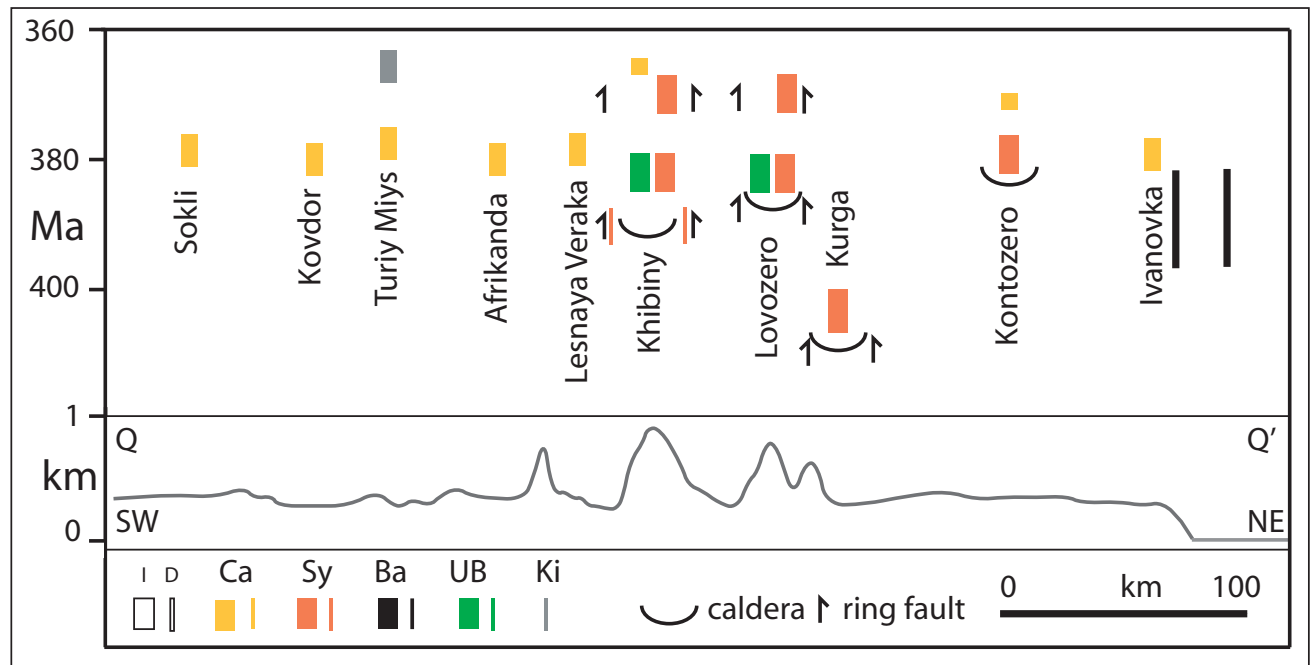

Figure 6. Simplified chronology of magmatic activity along the Kontozero Graben. Line of topographic section Q-Q' shown on Fig. 2. 'T' - Intrusion. 'D'- Dyke. Magmatism of carbonatite (Ca), nepheline-syenite (Sy), basaltic (Ba), ultrabasic (UB) and kimberlite (Ki) types.

centre (Arzamastsev \& Petrovsky, 2012) and occur more widely as outliers to the east (Fig. 2; Dunworth \& Bell, 2001). Along this part of the Barents Sea coast, postDevonian erosion has been confined to cover rocks. Basal Late Devonian-Early Carboniferous conglomerates at Lovozero and Kontozero contain clasts of rocks from the Archaean Murmansk and Central Kola Terranes that presently outcrop in the vicinity (Kirichenko, 1970), indicating only limited denudation of local basement since $390 \mathrm{Ma}$.
Intrusion of the main syenite plutonic complexes took place within the subsided Khibiny and Lovozero calderas. These intrusions extend to depths of $>14 \mathrm{~km}$ but each is estimated on the basis of gravimetric models of intrusion forms to have lost only $10 \%$ of its original volume to erosion (Arzamastsev et al., 2001). This represents postDevonian denudation of rock columns of respective heights of $2.4 \mathrm{~km}$ at Khibiny and $3.5 \mathrm{~km}$ at Lovozero (Fig. 7). To these estimates should be added 1-2 km for the original roof rocks also lost to denudation (Nivin, 2008b).

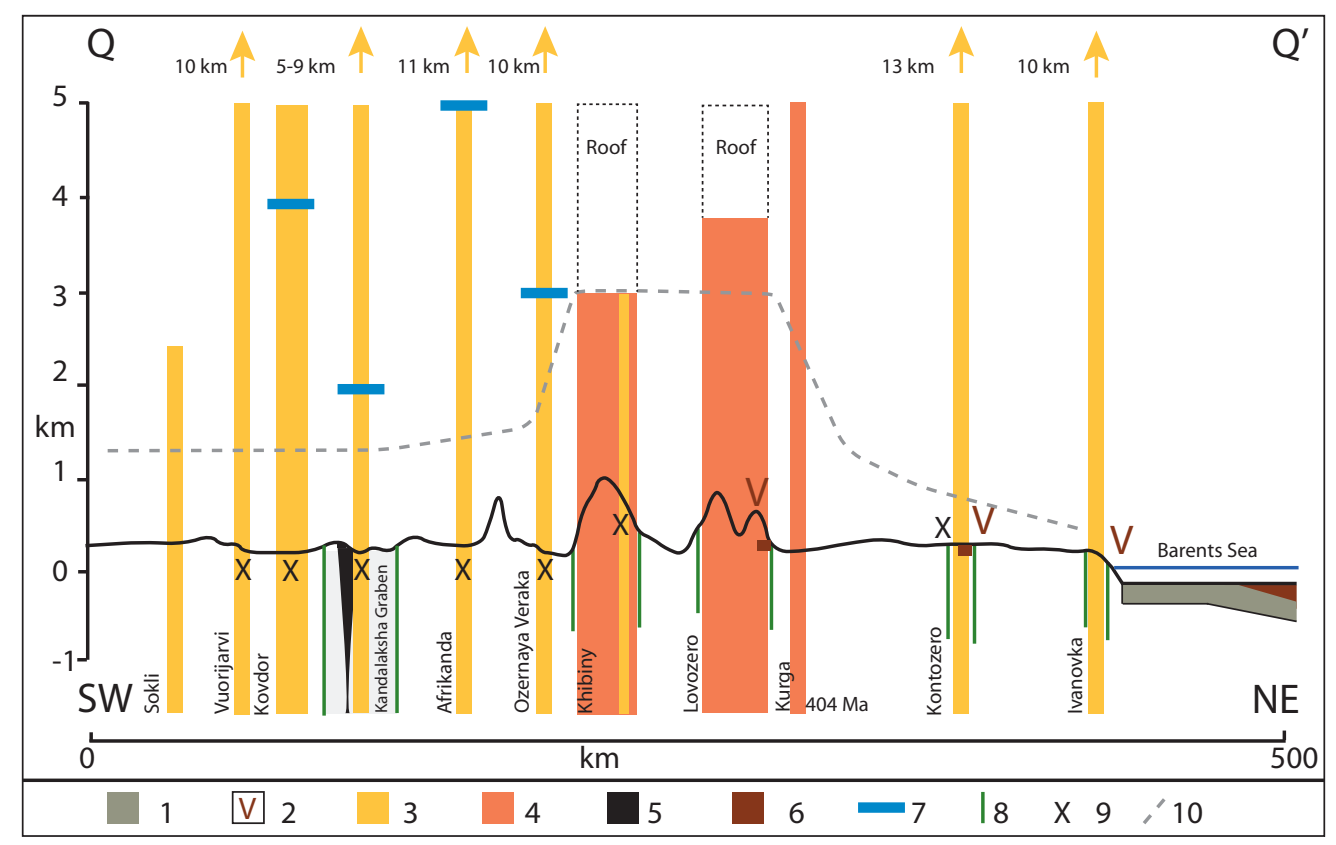

Figure 7. Denudation along a southwest-northeast transect from northern Finland to the Barents Sea. Line of section shown on Fig. 2. 1 - Riphean sedimentary rocks. 2 - Early to Middle Devonian volcanic rocks. 3 - Ultrabasic-alkaline complexes with carbonatites intruded at $\sim 379 \pm 5$ Ma. 4 Nepheline syenites intruded at 372-367 Ma. 5 - Kimberlites formed at 360 Ma. 6 - Devonian sedimentary rocks. 7 - Depth of erosion since cooling derived from the homogenisation temperature of fluid inclusions in quartz and apatite from late-stage ankeritic and dolomitic quartz-bearing carbonatite (Epshteyn \& Kaban'kov, 1984). 8 - Ring faults. 9 - Explosion breccia. 10 - Approximate position of the end-Devonian land surface. 
The latest igneous rocks include alkaline dyke swarms and picrite-carbonatite explosion pipes within the Main Ring fault zone at Khibiny (Ivanyuk et al., 2012). The late-stage dykes at Khibiny are degassed, indicating emplacement close to the contemporary land surface (Tolstikhin et al., 2002), an interpretation consistent with earlier views of the dykes as eruption channels for volcanic explosion fields since removed by erosion (Bulakh \& Ivanikov, 1984). Late-stage, low-temperature, hydrothermal alteration is common in both the Khibiny and the Lovozero intrusions (Men'shikov et al., 2006), requiring interaction with groundwater in the upper 2 $\mathrm{km}$ of the rock column (Nivin, 2008a, 2011).

The preservation of roof rocks, the limited depth of erosion of the main syenite intrusions and the presence of explosion pipes and near-surface hydrothermal effects (Fig. 7) support long-standing views that the depth of post-Devonian erosion for the Khibiny and Lovozero massifs is only a few $\mathrm{km}$ (Virovlyansky, 1975). The exposure of alkaline plutonic rocks at the present land surface requires, however, deep erosion during the magmatic phase. Large differences in erosion depths between the two major igneous centres and the surrounding country rocks are a product of large-scale differential movements within ring faults at 390-370 Ma (Fig. 6) and contemporaneous erosion (Ivanyuk et al., 2012).
Phoscorite-Carbonatite Pipes

The KAP includes many Phoscorite-Carbonatite pipes (PCPs) that are typically a few $\mathrm{km}$ in diameter and extend to depths of $>10 \mathrm{~km}$. Many PCPs have experienced a prolonged, multiphase, metasomatic-hydrothermal evolution (Williams, 2015). The PCPs have been used to estimate depths of erosion on the Kola Peninsula since intrusion in the Devonian (Fig. 7; Arzamastsev et al., 2000, 2001). The PCPs are interpreted, partly on the basis of gravity data, to have a common, verticallyzoned structure, with phoscorite and carbonatite dominating at the top of the pipes, above a zone of foidolite and a root of ultrabasic rocks. The current level of exposure of each carbonatite stock relates to erosion since intrusion (Arzamastsev et al., 2001). Three groups have been recognised (Fig. 8; Arzamastsev et al., 2000): (i) very deeply eroded pipes mainly in the southern part of the Kola Peninsula, where only the ultramafic bases of magma reservoirs have survived, indicating a vertical erosional thickness of $8-11 \mathrm{~km}$; (ii) a deeply eroded zone within the Kontozero Graben that extends from Kovdor to Khibiny-Lovozero with 5-9 km of erosion and (iii) a slightly eroded zone occupying the northern and western portions of the Kola Peninsula and extending into Finland, where post-intrusive erosion of the Seblyavr and Sokli intrusions does not exceed 1-2 $\mathrm{km}$. The juxtaposition of intrusions in the very deeply and deeply eroded groups indicates, however, that the

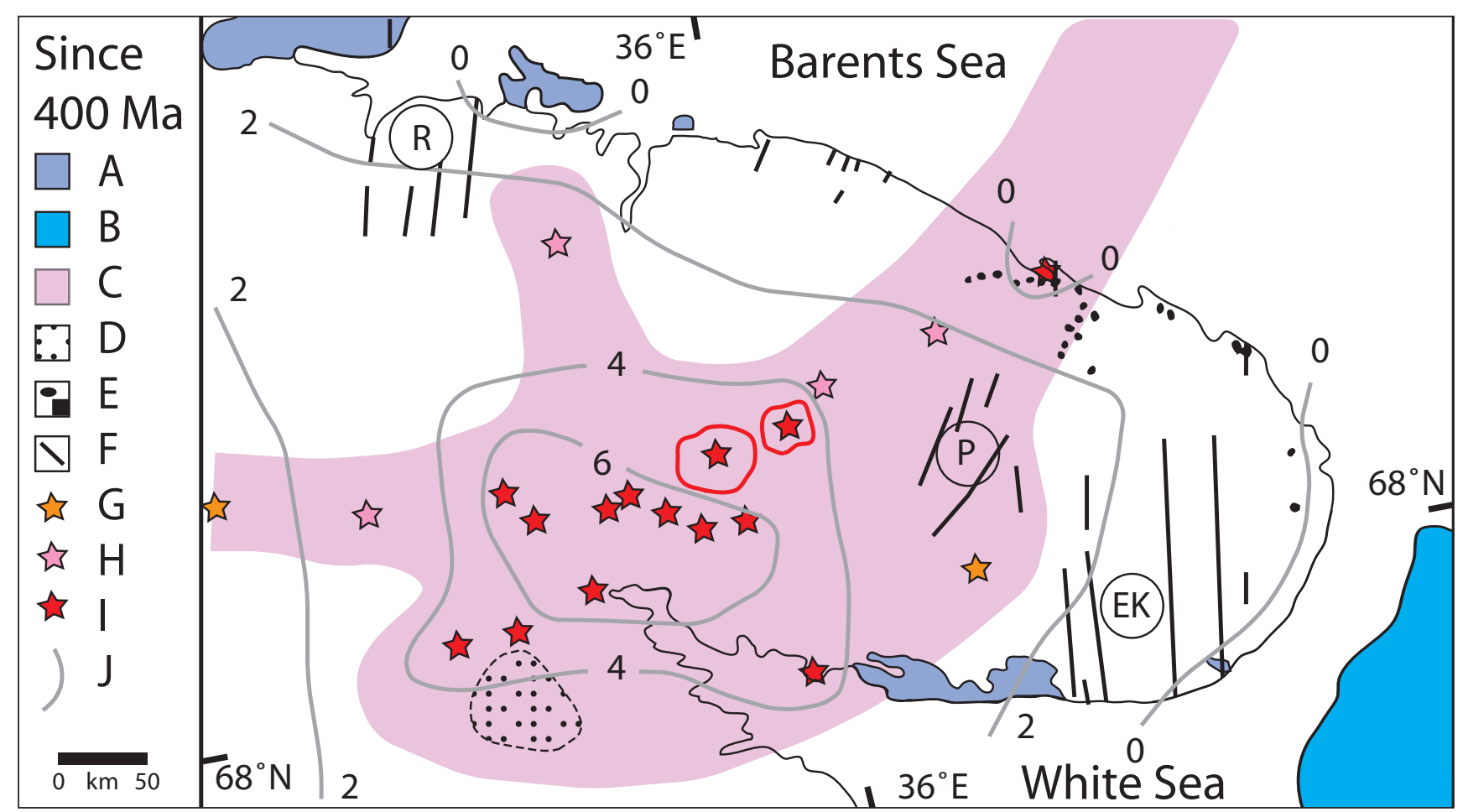

Figure 8. Schematic model of denudation patterns since $460 \mathrm{Ma}$. 'A' - Riphean sedimentary rocks. 'B' - Vendian sedimentary rocks. 'C' - Extent of Devonian alkaline magmatic activity. 'D' - Zone of Devonian diamondiferous dykes (after Terekhov et al., 2012). 'E' - Devonian lavas (after Dunworth \& Bell, 2001). 'F' - Phanerozoic tholeitic dykes of the Rybachiy (R), Pechenga (P) and eastern Kola (EK) swarms. 'G'- 'T' - KAP intrusions classified by depth of post-emplacement erosion. 'G' - Low (1-2 km), 'H'- Medium (5-9 km) and 'T'- High (8-11 km). Modified from Arzamastsev et al. (2001). 'J'-Isolines ( $\mathrm{km}$ ) for post-emplacement denudation. 
large differences in erosion depths must be a product of $\mathrm{km}$-scale displacement within ring faults rather than differential movement between basement blocks.

PCP emplacement on the Kola Peninsula involved multiple phases of igneous activity and large vertical movements within ring structures (Arzamastsev et al., 2013). Hence, the emplacement depths proposed for the carbonatite stocks need to be tested against other proxies (Fig. 7).

- In the most deeply eroded group of plutonic intrusions, fluid inclusions at Afrikanda indicate crystallisation at a depth of $5.4 \pm 0.8 \mathrm{~km}$ (Epshteyn \& Kaban'kov, 1984). At Ivanovka, exposed plutonic rocks emplaced at $371 \pm 8 \mathrm{Ma}$ (Arzamastsev \& Wu, 2014) and a depth of $\sim 10 \mathrm{~km}$ (Arzamastsev et al., 2001) occur close to remnants of Late Devonian volcanic rocks (Arzamastsev \& Petrovsky, 2012). Similarly, at Turiy Mys, exposed plutonic ultrabasic rocks formed at 377 $\pm 2 \mathrm{Ma}$ (Arzamastsev \& Wu, 2014) are found close to kimberlites formed at 370-360 Ma that incorporate garnet amphibolite xenoliths identical to rocks currently exposed at the surface and indicating emplacement within $2 \mathrm{~km}$ of the present land surface (Baluev \& Terekhov, 2006). A similar depth of emplacement is likely for late-stage carbonatite explosion breccias at Vuorijärvi, Salmagorsk, Osnaya Varaka, Afrikanda and several other alkaline magmatic centres (Fig. 9; Kapustin, 1983).

- In the intermediate group, emplacement depth at Kovdor is constrained by fluid inclusions in early apatites that record a fluid pressure of 1.1 to $1.5 \mathrm{kbar}$ corresponding to $3.5-5 \mathrm{~km}$ depth (Sokolov, 1981) and by the homogenisation temperature of fluid inclusions in quartz and apatite from late-stage ankeritic and dolomitic, quartz-bearing carbonatite at $4 \pm 0.7 \mathrm{~km}$ (Epshteyn \& Kaban'kov, 1984).

- In the slightly eroded group, the Sokli intrusion remains largely buried. Shallow emplacement of the Seblyavr mass, however, is not compatible with $\mathrm{He}$ isotopic data that instead places Seblyavr alongside hypabyssal ultrabasic, alkaline and carbonatitic intrusions at Kovdor, Vuorijärvi and Lesnaya Varaka (Tolstikhin et al., 1999).

These comparisons indicate that post-Devonian erosion depths based on models of carbonatite stock structure are often much greater than those based on other proxies (Fig. 7). Two main reasons are proposed for these differences. Firstly, the vertical structure proposed for the Kola PCPs may be over-simplified (Evzerov, 2001) and the pipes may have been emplaced at different depths in the upper crust (Arzamastsev et al., 2000). Secondly, multiphase intrusion, with, for example, six separate magmatic phases at Kovdor (Fontana, 2006), allows

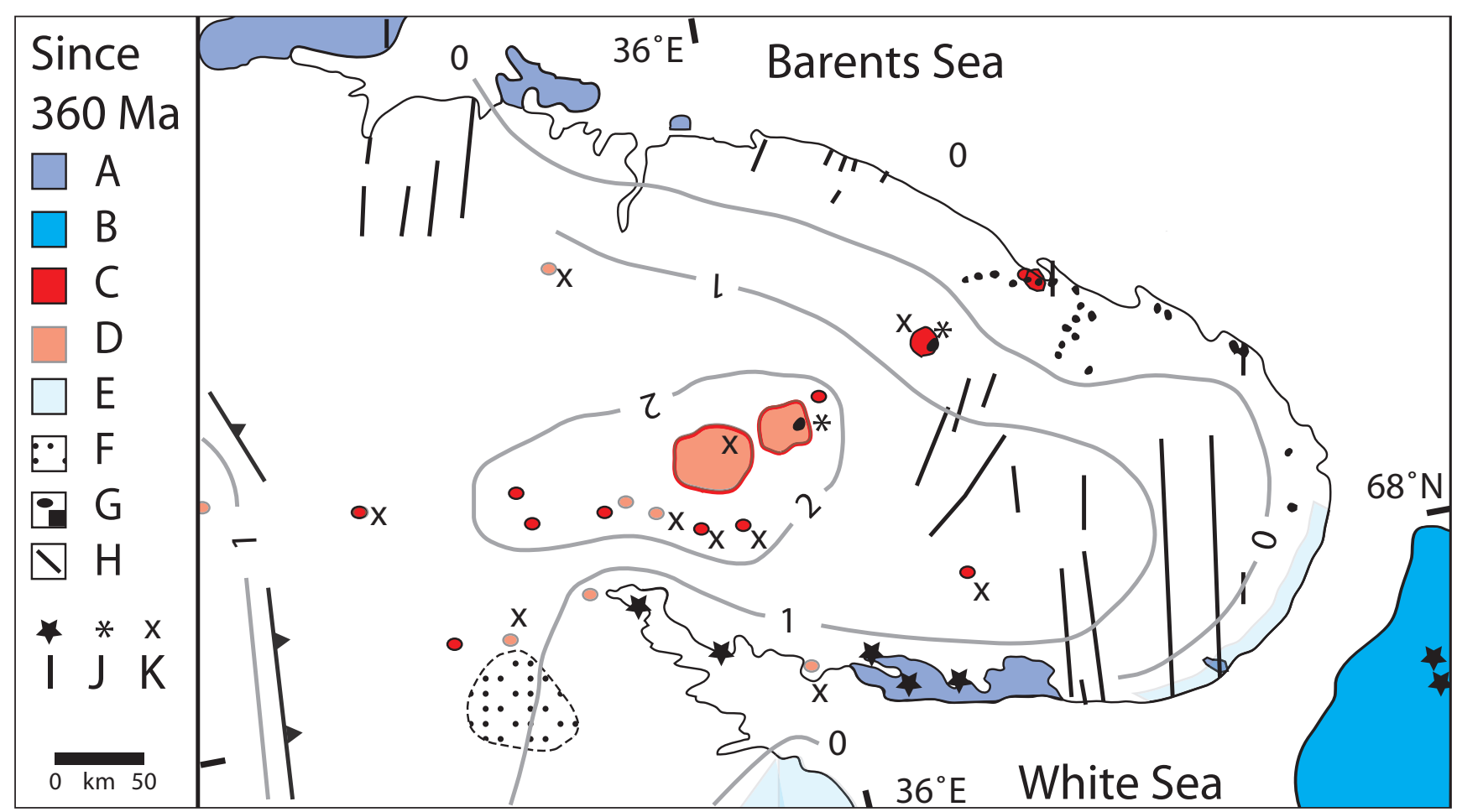

Figure 9. Schematic model of denudation patterns since $360 \mathrm{Ma}$. 'A' - Riphean sedimentary rocks. 'B' - Vendian sedimentary rocks. 'C' - KAP intrusions. ' $D$ ' - KAP intrusions with late stage hydrothermal effects. ' $E$ ' - Sub-Vendian peneplain. ' $F$ ' - Zone of Devonian diamondiferous dykes (after Terekhov et al., 2012). 'G' - Devonian lavas. 'H' - Phanerozoic tholeiitic dykes. 'I' - Kimberlites. 'J' - Late Devonian to Early Carboniferous sedimentary rocks. ' $K$ ' - Explosion breccias. Isolines $(\mathrm{km})$ show depths of post-360 Ma denudation. 
deep erosion to occur during the magmatic episode. In this case, only the latest dykes, explosion breccias and hydrothermal effects in a PCP constrain the level of the end-Devonian land surface.

\section{Kimberlites}

Kimberlites that conform to models of crater-diatremehypabyssal structure for explosively erupted pipes allow assessment of depths of erosion since eruption (Hawthorne, 1975). East of the Kola Peninsula, on the Winter Coast north of Arkangelsk (Fig. 9), Late Devonian kimberlite pipes intrude basement and Riphean and Vendian sedimentary rocks and retain infilled craters, indicating minimal erosion since intrusion (Mahotkin et al., 2000). On the Terskii coast of the Kola Peninsula (Fig. 2), diatremes and dykes emplaced between 370 and $360 \mathrm{Ma}$ (Arzamastsev \& Wu, 2014) cut through the heterogeneous basement consisting of early Archaean gneisses of the White Sea Group and Palaeoproterozoic granitoids, and penetrate the overlying Riphean sandstones of the Terskaya Formation, 200 to $500 \mathrm{~m}$ in thickness (Kalinkin et al., 1993). One pipe retains crater and vent facies (Kalinkin et al., 1993), consistent with $<0.5 \mathrm{~km}$ of post-emplacement erosion (Stanley et al., 2013). Xenoliths incorporated in kimberlite pipes during eruption provide important information on near-surface rocks present at the time of eruption at the eruption site (Nassichuk \& McIntyre, 1995; Cookenboo et al., 1998; Baluev \& Terekhov, 2006; Hanson et al., 2009). The clastic explosion dykes developed at Turiy Mys and near Kandalaksha contain mainly fragments of granite gneiss, amphibolite, carbonatite and Riphean sandstone, rocks known at the present-day erosion level (Baluev \& Terekhov, 2006). The absence of Vendian xenoliths implies that all Vendian cover had been eroded previously. Furthermore, the lack of Devonian lava xenoliths and the shallow depth of emplacement of these kimberlites requires that any thick cover of Devonian lava (Downes et al., 2005) that may have once existed along the Kandalaksha Graben had been removed by erosion by $360 \mathrm{Ma}$.

\section{Dykes}

Two distinct groups of alkaline and dolerite Neoproterozoic - early Phanerozoic dykes occur on the Kola Peninsula. Devonian alkaline dykes are found associated with nepheline syenites (Khibiny, Lovozero) and alkaline ultrabasic rocks (Kovdor, Afrikanda and others). The alkaline dykes occur within 5-15 km of KAP intrusions and fall within a zone of alkaline magmatism centred on Kandalaksha (Fig. 8; Arzamastsev et al., 2010). In contrast, dolerite dykes form autonomous swarms over the wider Kola region (Fig. 8; Arzamastsev et al., 2010). If these dolerite dykes fed lava fields then Devonian plateau basalts may have originally extended across the Kola Peninsula towards remnants exposed in Timan (Mahotkin et al., 2000). Other basaltic lavas erupted from feeder dykes covered parts of northern Kola, emanating from igneous centres in the East Barents basin (Fig. 3; Terekhov et al., 2012). K-Ar and Sm$\mathrm{Nd}$ dating methods indicate that the Rybachiy swarm $(600-540 \mathrm{Ma})$ is the oldest, whereas dolerite dykes in eastern Kola and Pechenga were emplaced at 380-300 Ma (Fig. 8; Arzamastsev et al., 2010). The alkaline and dolerite dykes are generally disjunct, but the dykes of alkaline rocks cut earlier dolerite dykes on the eastern Murmansk coast near Ivanovka (Fedotov, 2005). Both sets of dykes have undergone later, low-temperature, hydrothermal-metasomatic alteration, with formation of new magnetic minerals and secondary $\mathrm{Fe}, \mathrm{Cu}, \mathrm{Co}$ and $\mathrm{Ni}$ sulphides. The regional remagnetisation event is likely to be of Early Jurassic age, linking dyke alteration to the formation of the Barents Sea basalt province at 200-170 Ma (Veselovskiy et al., 2013).

Where dyke petrology or setting can be linked to emplacement depth then dykes become markers for later denudation. On the Kola Peninsula, such dyke characteristics include:

- Association with lava remnants, indicating negligible subsequent erosion of basement. Examples are known close to the Ivanovka (Arzamastsev et al., 2010) and Kontozero (Petrovsky et al., 2012) igneous centres (Figs. 8 \& 9).

- Presence of explosion breccias, indicating venting of dykes within $1 \mathrm{~km}$ of the surface as feeder channels for surface volcanic fields. Examples include Kandalaksha Bay (Beard et al., 1998), Turiy Mys (Downes et al., 2005), Khibiny (Ivanyuk et al., 2012), Kontozero (MacBride, 2005) and numerous PCPs (Kapustin, 1983), including Kovdor (Fig. 9; Mikhailova et al., in press).

- Dykes that are hydrothermally altered and mineralised, indicating interaction with meteoric waters in the upper $2 \mathrm{~km}$ of the crust (Genter \& Traineau, 1992). Examples include: 1. Late dykes associated with PCPs (Kapustin, 1983), 2. Late dykes in the major alkaline magmatic centres (Sindern et al., 2004; Men'shikov et al., 2006), 3. Extensive alteration in the Kola dyke swarms (Veselovskiy et al., 2013), and 4. $\mathrm{Pb}-\mathrm{Zn}$ vein mineralisation of Late Devonian age found associated with dykes in westernmost parts of the Kola Peninsula (Guise \& Roberts, 2002).

Collectively, the evidence from these dyke groups indicates that lowering of the end-Devonian land surface across much of the Kola Peninsula has been limited to $\sim 1-2 \mathrm{~km}$.

\section{Apatite Fission Track data}

A limited amount of Apatite and Zircon Fission Track (AFT and ZFT) data is available for Kola (Fig. 10; Rohrman, 1995; Hendriks \& Andriessen, 2002; Hendriks, 2003; Lorencak, 2003; Murrell, 2003; Hendriks et al., 2007). Long-term rock cooling rates can be converted to mean denudation rates on the assumptions that the 


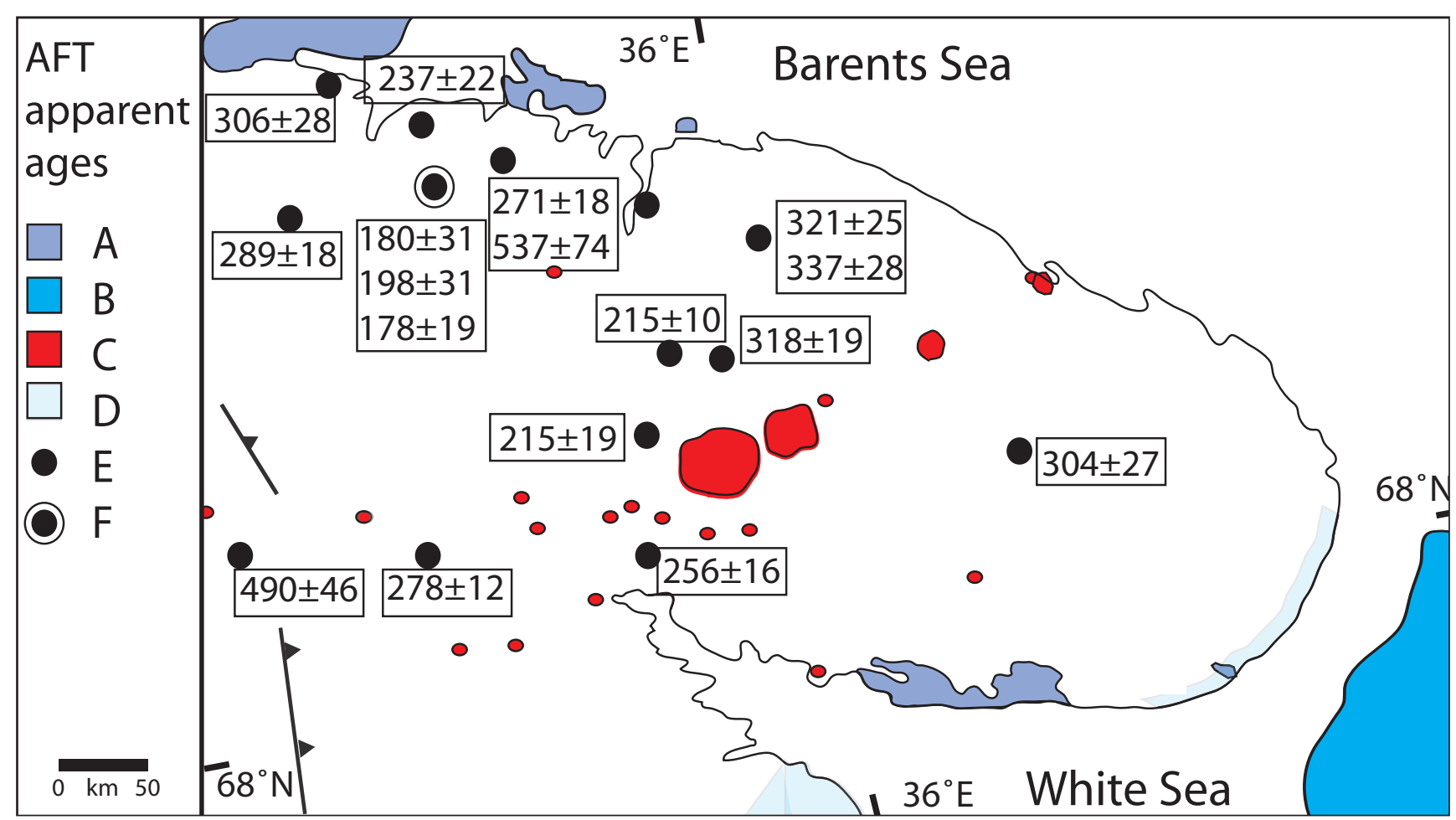

Figure 10. Apatite Fission Track (AFT) apparent ages for the Kola Peninsula and adjacent parts of Russia and Finland. 'A' - Riphean. 'B' - Vendian. 'C'-KAP intrusions. 'D'- Sub-Vendian peneplain. 'E' - AFT sample location. 'F' - Kola Superdeep Borehole (SG-3). AFT data at 1 sigma error.

uplifting rocks proceed through a horizontally-stratified, thermal boundary layer (the apatite partial annealing zone or APAZ) and that past and present geothermal gradients can be defined (Gunnell, 2000). In the Kola Superdeep borehole (SG-3), the geothermal gradient is $18^{\circ} \mathrm{C} / \mathrm{km}$ (Mottaghy et al., 2005). Assuming that AFT samples are not affected by reheating, for this geothermal gradient the APAZ is reached at $60-120^{\circ} \mathrm{C}$ (Gallagher et al., 1998) when the sample is within $3-6 \mathrm{~km}$ of the surface. The modern geothermal gradient on the Kola Peninsula is more complex than this, with greatest heat loss in the upper $2 \mathrm{~km}$ of the crust in the crucial PAZ and with significant lateral variations in heat flow. A total of 14 high-precision temperature logs and the re-evaluation of 22 analogue borehole logs from the 1960s across the Kola Peninsula yielded temperature gradients in the upper $2 \mathrm{~km}$ varying from 5 to $20 \mathrm{~K} / \mathrm{km}$ (Mottaghy et al., 2005), suggesting that heat flow has been strongly influenced by cold groundwaters generated during Pleistocene glaciations (Kukkonen et al., 1998; Vogt et al., 2014). With these geothermal gradients, the APAZ is reached at depths of $\geq 3 \mathrm{~km}$.

The pattern of AFT apparent ages across northern Fennoscandia is generally spatially consistent (Hendriks et al., 2007). AFT apparent ages from close to the North Atlantic margin fall in the range $90-150 \mathrm{Ma}$ (Hendriks \& Andriessen, 2002), whereas apparent ages for central and southern Finland are $>400 \mathrm{Ma}$ (Murrell, 2003; Murrell \& Andriessen, 2004). This reflects regional patterns of passive-margin uplift from the Late Cretaceous onwards and the consequent deep denudation of the rising Northern Scandes and its escarpment and foreland (Redfield \& Osmundsen, 2013). In contrast, the much older apparent ages around the Baltic are consistent with the wide extent of the sub-Cambrian peneplain, a timetransgressive erosion surface on which shallow shelf sedimentation commenced in the Middle Ordovician (Sturkell \& Lindström, 2004).

In contrast, the widely scattered AFT data for the Kola Peninsula are much less coherent (Fig. 10). AFT apparent ages at individual and adjacent sites differ by 103-266 Myr. A single apparent age of $490 \mathrm{Ma}$ from the Sokli area in northern Finland is much older than AFT apparent ages for Kovdor, $\sim 100 \mathrm{~km}$ to the east. In the upper 2.8 $\mathrm{km}$ in the Kola Superdeep borehole, AFT apparent ages fall within the Early Jurassic (Rohrman, 1995) and so are anomalously young for the region. In contrast, in northern Kola, on and near Sredniy, AFT apparent ages cluster around $300 \mathrm{Myr}$ in the Late Carboniferous-Early Permian. Ages along the Kontozero Graben are $~ 90$ Myr younger (Late Triassic). AFT data for the Barents Shelf show similar inconsistencies (Henriksen et al., 2011a). The currently available AFT data set for the Kola Peninsula indicates little more than Carboniferous to Triassic cooling. This is generally consistent with a phase of Early Mesozoic uplift and erosion indicated by delta progradation from the Kola Peninsula in the Late Permian (Wilson et al., 1999) and by rapid subsidence of the South Barents Basin from latest Carboniferous to earliest Triassic times (300-240 Ma) (O'Leary et al., 
2004). More detailed interpretation awaits fresh AFT and $\mathrm{U}-\mathrm{Th} / \mathrm{He}$ thermochronometric studies across the Kola Peninsula and adjacent areas.

\section{Synthesis}

The shield surface across the Kola Peninsula can be reconstructed before and after magmatism using depth indicators in the KAP (Figs. 8 \& 9):

At 460 Ma: Narrow bands of crystalline basement along the northern and eastern fringes of the Kola Peninsula remained buried by Riphean cover rocks and the thickness of Riphean rocks in the Kandalaksha Graben was considerably greater than today (Fig. 5; Zhuravlev \& Shipilov, 2007). Extrapolation of the Sub-Vendian Peneplain, already formed by $\sim 555 \mathrm{Ma}$, indicates that shield rocks in eastern Kola stood $>1 \mathrm{~km}$ higher than the current erosion level (Fig. 5). An old AFT apparent age in northern Finland (Fig. 10) indicates earlier cooling of crustal rocks below the PAZ, and, together with the limited erosion of the Sokli carbonatite pipe and the preservation of Early Cambrian sedimentary rocks in the Saarijärvi impact structure in Ostrobothnia (Fig. 1; Öhman \& Preeden, 2013), suggest removal of $<2 \mathrm{~km}$ of shield rock from above the backslope of the Saariselkä-Karelia escarpment. Within the core area of KAP magmatism (Fig. 8), exposure of the PCPs and the main syenite intrusions indicate that the shield surface stood up to $6 \mathrm{~km}$ higher. The overall pattern of uplift is consistent with previous reconstructions of doming of the Kola region (Nikishin et al., 1996; Arzamastsev et al., 2000, 2010; Guise \& Roberts, 2002) but shows both NE-SW and E-W-oriented axes of uplift along the deepseated Kontozero and Kandalaksha structures.

At 360 Ma: The Devonian lavas that rest on basement and Riphean cover on the northeastern fringe of the Kola Peninsula mark a marginal band where the shield surface was already close to its current erosion level at the close of KAP magmatism (Fig. 9). Kimberlite pipes and dykes along the north shore of Kandalaksha Bay remain within $1 \mathrm{~km}$ of the end-Devonian land surface. More widely, latestage explosion breccias and hydrothermal effects define a broad zone where the land surface stood $\leq 2 \mathrm{~km}$ above its current level (Fig. 9). The overall pattern indicates that uplift was mainly along the Kontozero Graben.

Comparison of the two reconstructions (Figs. 8 \& 9) indicates that up to $4 \mathrm{~km}$ of crystalline basement was removed from central Kola during the 100 Myr KAP magmatic phase. The occurrence of deep erosion during magmatism is supported by the juxtaposition of exposed hypabyssal plutons with (i) lavas, (ii) degassed late-stage dykes that probably erupted to the surface and (iii) near-surface hydrothermal effects. Intrusion within ring faults, as at Khibiny, Lovozero and Kontozero, allowed localised uplift, unroofing and deep erosion of igneous masses whilst surrounding areas experienced much less denudation, as in the Tertiary Igneous Province of western Scotland (Hall, 1991). Elevation differences between the Khibiny and Lovozero massifs and the surrounding shield rocks established at the start of the KAP magmatic phase are also apparent in the patterns of Early Mesozoic AFT closure ages (Fig. 10) and imply maintenance of high relief around the syenite massifs from 460 to $300 \mathrm{Ma}$.

AFT cooling ages for the Kola Peninsula are younger than the KAP magmatic phase. Moreover, when the AFT ages are matched to known cooling rates on Kola then 3-6 km of erosion is required after the close of KAP magmatism. As geological evidence shows that basement surfaces had been lowered to within $0-2 \mathrm{~km}$ of the current erosion level by $360 \mathrm{Ma}$, this deep erosion, if real, must have been mainly confined to thick cover rocks. Yet Riphean and Vendian cover rocks had been largely or entirely removed from the Kandalaksha-Kontozero graben by the end of alkaline magmatism (Veselovskiy et al., 2013). Hence, the reported AFT apparent ages require that several $\mathrm{km}$ of Devonian to Triassic volcanic and sedimentary rocks covered the Kola Peninsula until removal in the Early Mesozoic. Thick lavas may been extruded extensively on the Kola Peninsula during the Late Devonian (Downes et al., 2005) but their absence as xenoliths in the Kandalaksha kimberlites does not support retention of a thick cover over the Kola Peninsula into the Carboniferous. The presence of thick Palaeozoic cover rocks on the Kola Peninsula is also not a feature of recent reconstructions of the tectonostratigraphy of the southern Barents Sea (Henriksen et al., 2011b). In the Kola Peninsula, AFT results appear to identify an important phase of Early Mesozoic uplift but to considerably overestimate depths of denudation at that time. One reason for this disparity may lie in regional Early Jurassic reheating (Veselovskiy et al., 2013). Similar mismatches between geological and geomorphological indicators of denudation depths and AFT results have, however, been reported from other shield and platform areas (Gunnell, 2000; Hall \& Bishop, 2002; Gunnell et al., 2003; Peulvast et al., 2008; Flowers \& Kelley, 2011). Specifically, identification of reheating in AFT studies has led to appeals for burial by thick sedimentary covers of which few, if any traces remain (Gunnell, 2000). The constraints provided by long-term denudation indicators in areas such as the Kola Peninsula are a neglected component in the vigorous debates over the systematics and meaning of AFT analyses on the Fennoscandian Shield (Murrell \& Andriessen, 2004; Hendriks \& Redfield, 2005; Bonow et al., 2006; Larson et al., 2006; Kohn et al., 2009).

Evidence from the KAP indicates that average erosion rates during the magmatic phase were $\sim 40 \mathrm{~m} / \mathrm{Myr}$ in the central Kola Peninsula, declining to $<20 \mathrm{~m} / \mathrm{Myr}$ in peripheral areas. Erosion rates were probably significantly greater during the climax of magmatism and 
uplift between 390 and $370 \mathrm{Ma}$. Since the end of KAP magmatism at $360 \mathrm{Ma}$, erosion rates in central Kola have been much lower at $<6 \mathrm{~m} / \mathrm{Myr}$. Similar contrasts in erosion rates between magmatic and post-magmatic phases are reported from southern Africa (Stanley et al., 2013) and are typical of post-orogenic denudation (Calvet et al., 2015). Around the margins of the Kola Peninsula and in adjacent areas of northern Finland and Karelia, a maximum $1 \mathrm{~km}$ depth of shield and cover rocks has been removed since $360 \mathrm{Ma}$, giving average erosion rates of $<3 \mathrm{~m} / \mathrm{Myr}$. As uplift-driven episodes of more rapid erosion occurred in the Early Mesozoic (O'Leary et al., 2004) and Pliocene (Knies et al., 2014) on the northern Norwegian margin, it is likely that the Kola Peninsula has experienced long intervals of negligible erosion. Since the end of KAP magmatism, the Kola fragment of the Fennoscandian Shield has developed under a cratonic tectonic regime (Fairbridge \& Finkl, 1980) of slow, episodic uplift and denudation.

Erosion rates over the last $360 \mathrm{Myr}$ on the Kola Peninsula and in adjacent parts of Karelia and Finnish Lapland are similar to estimates for the Canadian Shield of $<2.5$ $\mathrm{m} / \mathrm{Myr}$ since $1.7 \mathrm{Ga}$ (Flowers et al., 2006) and 2-8 m/ Myr since the Palaeozoic (Peulvast et al., 2009). There is growing evidence that such low erosion rates are typical of many shield regions (Gunnell, 2003; Peulvast et al., 2008; Beauvais \& Chardon, 2013). Further refinement of the tempo of denudation in northern Fennoscandia requires application of low-temperature thermochronometry (Stanley et al., 2013), combined with detailed analysis of the regional geomorphological development and the dating of old weathering mantles (Pekkala \& Yevzerov, 1990; Gilg et al., 2013).

\section{Conclusions}

Post-Devonian denudation rates on the shield rocks of the Kola Peninsula, NW Russia, have varied in space and time. Data from the distribution of Riphean and Vendian cover rocks, depth indicators from the Kola Alkaline Province and AFT results generally give consistent patterns that indicate:

1. Negligible long-term denudation of shield rocks around the periphery of the Kola Peninsula indicated by the survival of Riphean cover rocks and Late Devonian lavas, kimberlite crater facies and near-surface dykes.

2. Removal of 4-6 km of rock from the area with the main concentration of igneous centres on the Kola Peninsula during doming associated with the KAP magmatic phase between 460 and $360 \mathrm{Ma}$. This deep denudation is indicated by the emplacement depths of alkaline intrusions and Phoscorite-Carbonatite pipes and involved the removal of shield rocks, Riphean and Vendian sedimentary cover and Early Devonian lavas.
3. Much lower depths of erosion on the Kola Peninsula since $360 \mathrm{Ma}$. Extensive, shallow, late-stage magmatism associated with PCPs, dykes and the large alkaline intrusions in the KAP indicates that erosion depths nowhere exceeded $2 \mathrm{~km}$. Post-Devonian denudation has removed $<1 \mathrm{~km}$ of rock from the margins of the Kola Peninsula and the backslope of the Saariselkä-Karelia scarp in northern Finland.

4. AFT data point to an important phase of erosion in the Early Mesozoic. Depths of unroofing of 3-5 $\mathrm{km}$ based on AFT cooling ages for this later phase, however, are in conflict with the evidence of much lesser erosion provided by the late-stage KAP intrusions and require unrealistic depths of former Devonian to Triassic cover rocks.

5. Mean denudation rates were greatest $(40 \mathrm{~m} / \mathrm{Myr})$ in the central Kola Peninsula during the KAP magmatic phase. Post-Devonian rates across the Kola Peninsula and adjacent shield areas were much lower $(<3-6 \mathrm{~m} /$ Myr) and are compatible with low long-term denudation rates for other shield areas.

Accelerated erosion on the Kola Peninsula during the Phanerozoic was confined to the period of KAP magmatism. Since $360 \mathrm{Ma}$, this shield region has probably supplied a total of $\sim 1 \mathrm{~km}$ of rock waste to the Barents Sea basin and evolved under a cratonic regime of slow erosion. Both during and since KAP magmatism, denudation has been spatially variable, with greatest erosion in the area around the main KAP intrusions.

Acknowledgements. Critical comments by referees Victor Melezhik and Tim Redfield led to substantial improvements in this paper.

\section{Reference list}

André, M.-F., Peulvast, J.-P., Godard, A. \& Sellier, D. 2001: Landscape Development in Arctic, Sub-Arctic and Circum-Arctic Shield Environments. In Godard, A., Lagasquie, J.-J. \& Lageat, Y. (eds.): Basement regions, Springer, Berlin, pp. 199-220.

Artemieva, I.M. 2003: Lithospheric structure, composition, and thermal regime of the East European Craton: implications for the subsidence of the Russian platform. Earth and Planetary Science Letters $213,431-446$.

Arzamastsev, A. \& Petrovsky, M. 2012: Alkaline volcanism in the Kola Peninsula, Russia: Paleozoic Khibiny, Lovozero and Kontozero calderas. Proceedings of the MSTU 15, 277-299.

Arzamastsev, A.A. \& Wu, F.-Y. 2014: U-Pb geochronology and Sr-Nd isotopic systematics of minerals from the ultrabasic-alkaline massifs of the Kola province. Petrology 22, 462-479.

Arzamastsev, A.A., Glaznev, V., Raevsky, A. \& Arzamastseva, L. 2000: Morphology and internal structure of the Kola Alkaline intrusions, NE Fennoscandian Shield: 3D density modelling and geological implications. Journal of Asian Earth Sciences 18, 213-228.

Arzamastsev, A.A., Bea, F., Glaznev, V., Arzamastseva, L. \& Montero, P. 2001: Kola alkaline province in the Paleozoic: evaluation of primary mantle magma composition and magma generation conditions. Russian Journal of Earth Sciences 3, 3-24. 
Arzamastsev, A., Arzamastseva, L., Travin, A., Belyatsky, B., Shamatrina, A., Antonov, A., Larionov, A., Rodionov, N. \& Sergeev, S. 2007 Duration of formation of magmatic system of polyphase Paleozoic alkaline complexes of the central Kola: U-Pb, Rb-Sr, Ar-Ar data. Doklady Earth Sciences 413, 432-436.

Arzamastsev, A.A., Fedotov, Z.A., Arzamastseva, L.V. \& Travin, A.V. 2010: Paleozoic tholeiite magmatism in the Kola igneous province: Spatial distribution, age, relations with alkaline magmatism. Doklady Earth Sciences 430, 205-209.

Arzamastsev, A.A., Arzamastseva, L., Zhirova, A. \& Glaznev, V. 2013: Model of formation of the Khibiny-Lovozero ore-bearing volcanicplutonic complex. Geology of Ore Deposits 55, 341-356.

Ault, A.K., Flowers, R.M. \& Bowring, S.A. 2009: Phanerozoic burial and unroofing history of the western Slave craton and Wopmay orogen from apatite (U-Th)/He thermochronometry. Earth and Planetary Science Letters 284, 1-11.

Baluev, A. \& Terekhov, E. 2006: Different-depth xenoliths from Devonian intrusions of the Kola peninsula: Key to deciphering paleogeodynamic settings of alkaline magmatism. Doklady Earth Sciences $407,167-171$.

Baluev, A., Przhiyalgovskii, E. \& Terekhov, E. 2009: New data on tectonics of Onega-Kandalaksha paleorift (The White Sea). Doklady Earth Sciences 425, 249-252.

Beard, A., Downes, H., Hegner, E., Sablukov, S., Vetrin, V. \& Balogh, K. 1998: Mineralogy and geochemistry of Devonian ultramafic minor intrusions of the southern Kola Peninsula, Russia: implications for the petrogenesis of kimberlites and melilitites. Contributions to Mineralogy and Petrology 130, 288-303.

Beauvais, A. \& Chardon, D. 2013: Modes, tempo, and spatial variability of Cenozoic cratonic denudation: The West African example. Geochemistry, Geophysics, Geosystems 14, 1590-1608.

Beckinsale, R.D., Reading, H.G. \& Rex, D.C. 1975: Potassium-argon ages for basic dykes from East Finnmark: stratigraphic and structural implications. Scottish Journal of Geology 12, 51-65.

Belton, D.X., Brown, R.W., Kohn, B.P., Fink, D. \& Farley, K.A. 2004: Quantitative resolution of the debate over antiquity of the central Australian landscape: implications for the tectonic and geomorphic stability of cratonic interiors. Earth and Planetary Science Letters 219, 21-34.

Bonow, J.M., Japsen, P., Lidmar-Bergström, K., Chalmers, J.A. \& Pedersen, A.K. 2006: Cenozoic uplift of Nuussuaq and Disko, West Greenland--elevated erosion surfaces as uplift markers of a passive margin. Geomorphology 80, 325-327.

Bulakh, A. \& Ivanikov, V. 1984: The problems of mineralogy and petrology of carbonatites (in Russian). Leningrad State University, Leningrad, $242 \mathrm{pp}$.

Calvet, M., Gunnell, Y. \& Farines, B. 2015: Flat-topped mountain ranges: their global distribution and value for understanding the evolution of mountain topography. Geomorphology. 241, 255-291

Claesson, S., Vetrin, V., Bayanova, T. \& Downes, H. 2000: U-Pb zircon ages from a Devonian carbonatite dyke, Kola peninsula, Russia: a record of geological evolution from the Archaean to the Palaeozoic. Lithos 51, 95-108.

Cookenboo, H.O., Orchard, M.J. \& Daoud, D.K. 1998: Remnants of Paleozoic cover on the Archean Canadian Shield: Limestone xenoliths from kimberlite in the central Slave craton. Geology 26, 391394.

Daly, J.S., Balagansky, V.V., Timmermann, M.J. \& Whitehouse, M.J. 2006: The Lapland-Kola orogen: Palaeoproterozoic collision and accretion of the northern Fennoscandian lithosphere. In Gee, D.G. \& Stephenson, R.A. (eds.): European Lithosphere Dynamics, Geological Society, London, Memoirs 32, 579-598.

Davids, C., Wemmer, K., Zwingmann, H., Kohlmann, F., Jacobs, J. \& Bergh, S.G. 2013: K-Ar illite and apatite fission track constraints on brittle faulting and the evolution of the northern Norwegian passive margin. Tectonophysics 608, 196-211.
Downes, H., Balaganskaya, E., Beard, A., Liferovich, R. \& Demaiffe, D. 2005: Petrogenetic processes in the ultramafic, alkaline and carbonatitic magmatism in the Kola Alkaline Province: A review. Lithos 85, 48-75.

Dunworth, E.A. \& Bell, K. 2001: The Turiy massif, Kola Peninsula, Russia: isotopic and geochemical evidence for multi-source evolution. Journal of Petrology 42, 377-405.

Ebert, K., Hättestrand , C., Hall, A.M. \& Alm, G. 2011: DEM identification of macro-scale stepped relief in arctic northern Sweden. Geomorphology 132, 339-350.

Eidvin, T., Riis, F. \& Rasmussen, E.S. 2014: Oligocene to Lower Pliocene deposits of the Norwegian continental shelf, Norwegian Sea, Svalbard, Denmark and their relation to the uplift of Fennoscandia: a synthesis. Marine and Petroleum Geology. 56, 184-221.

Epshteyn, Y.M. \& Kaban'kov, Y.V. 1984: The depth of emplacement and mineral potential of ultramafic, ijolite and carbonatite plutons. International Geology Review 26, 1402-1415.

Evzerov, V.Y. 2001: Placer Deposits As Unique Formations in the Loose Cover of the Baltic Shield. Lithology and Mineral Resources 36, 109115.

Fairbridge, R.W. \& Finkl, C.W. 1980: Cratonic erosional unconformities and peneplains. Journal of Geology 88, 69-86.

Fedotov, Z.A. 2005: Mafic dykes of the Kola region. In Vuollo, J.I. (ed.): Dyke swarms - time markers of crustal evolution, Geological Survey of Finland, Rovaniemi, pp. 61-63.

Flowers, R.M. \& Kelley, S.A. 2011: Interpreting data dispersion and "inverted" dates in apatite (U-Th)/He and fission-track datasets: an example from the US midcontinent. Geochimica et Cosmochimica Acta 75, 5169-5186.

Flowers, R.M., Bowring, S.A. \& Reiners, P.W. 2006: Low long-term erosion rates and extreme continental stability documented by ancient (U-Th)/He dates. Geology 34, 925-928.

Fontana, J. 2006: Phoscorite-Carbonatite Pipe Complexes. Platinum Metals Review 50, 134-142.

Gallagher, K., Brown, R. \& Johnson, C. 1998: Fission track analysis and its applications to geological problems. Annual Review of Earth and Planetary Sciences 26, 519-572.

Genter, A. \& Traineau, H. 1992: Borehole EPS-1, Alsace, France: preliminary geological results from granite core analyses for Hot Dry Rock research. Scientific Drilling 3, 205-214.

Gilg, H.A., Hall, A.M., Ebert, K. \& Fallick, A.E. 2013: Cool kaolins in Finland. Palaeogeography, Palaeoclimatology, Palaeoecology 392, 454-462.

Gorokhov, I., Mel'nikov, N., Negrutsa, V., Turchenko, T. \& Kutyavin, E. 2002: The Multistage Illite Evolution in Upper Proterozoic Claystones from the Srednii Peninsula, Murmansk Coast of the Barents Sea. Lithology and Mineral Resources 37, 162-179.

Grazhdankin, D. 2003: Structure and depositional environment of the Vendian Complex in the southeastern White Sea area. Stratigraphy and Geological Correlation 11,313-331.

Guise, P.G. \& Roberts, D. 2002: Devonian ages from ${ }^{40} \mathrm{Ar} /{ }^{39} \mathrm{Ar}$ dating of plagioclase in dolerite dykes, eastern Varanger Peninsula, North Norway. Norges geologiske undersøkelse 440, 27-37.

Gunnell, Y. 2000: Apatite fission track thermochronology: An overview of its potential and limitations in geomorphology. Basin Research 12, 115-132.

Gunnell, Y. 2003: Radiometric ages of laterites and constraints on longterm denudation rates in West Africa. Geology 31, 131-134.

Gunnell, Y., Gallagher, K., Carter, A., Widdowson, M. \& Hurford, A.J. 2003: Denudation history of the continental margin of western peninsular India since the early Mesozoic - reconciling apatite fission-track data with geomorphology ${ }^{\star} 1$. Earth and Planetary Science Letters 215, 187-201.

Hall, A.M. 1991: Pre-Quaternary landscape evolution in the Scottish Highlands. Transactions of the Royal Society of Edinburgh: Earth Sciences $82,1-26$ 
Hall, A.M. \& Bishop, P. 2002: Scotland's denudational history: an integrated view of erosion and sedimentation at an uplifted passive margin. In Doré, A.G., Cartright, J.A., Stoker, M.S., Turner, J.P.\& White, N. (eds.): Exhumation of the North Atlantic margin: Timings, Mechanisms and Implications for Petroleum Exploration, Geological Society of London Special Publications 196, pp. 271-290.

Hanson, E., Moore, J., Bordy, E., Marsh, J., Howarth, G. \& Robey, J. 2009: Cretaceous erosion in central South Africa: Evidence from uppercrustal xenoliths in kimberlite diatremes. South African Journal of Geology 112, 125-140.

Hawthorne, J. 1975: Model of a kimberlite pipe. Physics and Chemistry of the Earth 9, 1-15.

Hendriks, B. 2003: Cooling and Denudation of the Norwegian and Barents Sea Margins, Northern Scandinavia. Constrained by apatite fission track and (U-Th)/He thermochronology. Vrije Universiteit Amsterdam, Amsterdam, $192 \mathrm{pp}$.

Hendriks, B.W. \& Andriessen, P.A. 2002: Pattern and timing of the post-Caledonian denudation of northern Scandinavia constrained by apatite fission-track thermochronology. In Doré, A.G., Cartright, J.A., Stoker, M.S., Turner, J.P. \& White, N. (eds.): Exhumation of the North Atlantic margin: Timings, Mechanisms and Implications for Petroleum Exploration, Geological Society of London Special Publications 196, pp. 117-137.

Hendriks, B. \& Redfield, T. 2005: Apatite fission track and (U-Th)/He data from Fennoscandia: An example of underestimation of fission track annealing in apatite. Earth and Planetary Science Letters 236, 443-458.

Hendriks, B., Andriessen, P., Huigen, Y., Leighton, C., Redfield, T., Murrell, G., Gallagher, K. \& Nielsen, S.B. 2007: A fission track data compilation for Fennoscandia. Norwegian Journal of Geology 87, 143-155.

Henriksen, E., Bjørnseth, H., Hals, T., Heide, T., Kiryukhina, T., Kløvjan, O., Larssen, G., Ryseth, A., Rønning, K. \& Sollid, K. 2011a: Uplift and erosion of the greater Barents Sea: impact on prospectivity and petroleum systems. In Spencer, A.M.,Embry, A.F., Gautier, D.L., Stoupakova, A.V. \& Sørensen, K. (eds.): Arctic Petroleum Geology, Geological Society of London Memoirs 35, pp. 271-281.

Henriksen, E., Ryseth, A., Larssen, G., Heide, T., Rønning, K., Sollid, K. \& Stoupakova, A. 2011b: Tectonostratigraphy of the greater Barents Sea: implications for petroleum systems. In Spencer, A.M.,Embry, A.F., Gautier, D.L., Stoupakova, A.V. \& Sørensen, K., Arctic Petroleum Geology (eds.): Geological Society of London Memoirs 35, pp. 163-195.

Ivanova, N.M. 2001: The geological structure and petroleum potential of the Kola-Kanin Monocline, Russian Barents Sea. Petroleum Geoscience 7, 343-350.

Ivanyuk, G., Yakovenchuk, V., Pakhomovsky, Y., Konoplyova, N., Kalashnikov, A., Mikhailova, J. \& Goryainov, P. 2012: Self-organization of the Khibiny alkaline massif (Kola Peninsula, Russia). Earth Sciences, InTech, Rijeka, Croatia, 131-156.

Kalinkin, M., Arzamastsev, A. \& Polyakov, I. 1993: Kimberlites and related rocks of the Kola region. Petrology 1, 173-180.

Kapustin, Y.L. 1983: Explosion pipes in carbonatite complexes. International Geology Review 25, 1187-1198.

Kirichenko, L.A. 1970: The Kontozerskaya Series of Carboniferous Rocks on the Kola Peninsula (in Russian). Izdat. Nedra, Moscow, 110 pp.

Knies, J., Mattingsdal, R., Fabian, K., Grøsfjeld, K., Baranwal, S., Husum, K., De Schepper, S., Vogt, C., Andersen, N., Matthiessen, J., Andreassen, K., Jokat, W., Nam, S.-I. \& Gaina, C. 2014: Effect of early Pliocene uplift on late Pliocene cooling in the Arctic-Atlantic gateway. Earth and Planetary Science Letters 387, 132-144.

Kogarko, L.N. 1987: Alkaline rocks of the eastern part of the Baltic Shield (Kola Peninsula). Geological Society, London, Special Publications 30, 531-544.

Kohn, B.P., Lorencak, M., Gleadow, A.J.W., Kohlmann, F., Raza, A., Osadetz, K.G. \& Sorjonen-Ward, P. 2009: A reappraisal of low-temper- ature thermochronology of the eastern Fennoscandia Shield and radiation-enhanced apatite fission-track annealing. In

Lisker, F., Ventura, B. \& Glasmacher, U.A.: Thermochronological Methods: From Palaeotemperature Constraints to Landscape Evolution Models, Geological Society of London Special Publications 324, pp. 193-216.

Kramm, U., Kogarko, L., Kononova, V. \& Vartiainen, H. 1993: The Kola Alkaline Province of the CIS and Finland: Precise Rb区 Sr ages define 380-360 Ma age range for all magmatism. Lithos 30, 33-44.

Kukkonen, I., Gosnold, W. \& Šafanda, J. 1998: Anomalously low heat flow density in eastern Karelia, Baltic Shield: a possible palaeoclimatic signature. Tectonophysics 291, 235-249.

Lahtinen, R., Garde, A.A. \& Melezhik, V.A. 2008: Paleoproterozoic evolution of Fennoscandia and Greenland. Episodes 31, 20-28.

Larson, S.Å., Cederbom, C.E., Tullborg, E.-L. \& Stiberg, J.-P. 2006: Comment on "Apatite fission track and (U-Th)/He data from Fennoscandia: An example of underestimation of fission track annealing in apatite" by Hendriks and Redfield [Earth Planet. Sci. Lett. 236 (443-458)]. Earth and Planetary Science Letters 248, 561-568.

Lidmar-Bergström, K. 1996: Long term morphotectonic evolution in Sweden. Geomorphology 16, 33-35.

Lidmar-Bergström, K. 1999: Uplift histories revealed by landforms of the Scandinavian domes. In Smith, B.J., Whalley, W.B. \& Warke, P.A. (eds.): Uplift, Erosion and Stability: Perspectives on Long-Term Landscape Development, Geological Society of London Special Publications 162, pp. 85-91.

Lidmar-Bergström, K., Näslund, J.-O., Ebert, K., Neubeck, T. \& Bonow, J. 2007: Cenozoic landscape development on the passive margin of northern Scandinavia. Norwegian Journal of Geology 87, 181-196.

Lidmar-Bergström, K., Bonow, J.M. \& Japsen, P. 2012: Stratigraphic Landscape Analysis and geomorphological paradigms: Scandinavia as an example of Phanerozoic uplift and subsidence. Global and Planetary Change 100, 153-171.

Lorencak, M. 2003: Low temperature thermochronology of the Canadian and Fennoscandian Shields: Integration of apatite fission track and $(\mathrm{U}-\mathrm{Th}) / \mathrm{He}$ methods. $\mathrm{PhD}$ thesis, University of Melbourne, School of Earth Sciences, 296 pp.

MacBride, L.M. 2005: A comparative study of the petrology, mineralogy and geochemistry of kimberlite-like and carbonatitic rocks from Kontozero (Kola Peninsula, Russia) and bona fide kimberlites. University of Manitoba, Winnipeg, 364 pp.

Mahotkin, I.L., Gibson, S.A., Thompson, R.N., Zhuravlev, D.Z. \& Zherdev, P.U. 2000: Late Devonian Diamondiferous Kimberlite and Alkaline Picrite (Proto-kimberlite?) Magmatism in the Arkhangelsk Region, NW Russia. Journal of Petrology 41, 201-227.

Martin, M.W., Grazhdankin, D.V., Bowring, S.A., Evans, D.A.D., Fedonkin, M.A. \& Kirschvink, J.L. 2000: Age of Neoproterozoic bilatarian body and trace fossils, White Sea, Russia: Implications for metazoan evolution. Science 288, 841-845.

Men'shikov, Y.P., Krivovichev, S.V., Pakhomovsky, Y.A., Yakovenchuk, V.N., Ivanyuk, G.Y., Mikhailova, J.A., Armbruster, T. \& Selivanova, E.A. 2006: Chivruaiite, $\mathrm{Ca} 4(\mathrm{Ti}, \mathrm{Nb}) 5$ [(Si6O17) 2 [(OH, O) 5]. $13-14 \mathrm{H} 2 \mathrm{O}$, a new mineral from hydrothermal veins of Khibiny and Lovozero alkaline massifs. American Mineralogist 91, 922-928.

Mikhailova, J., Kalashnikov, A., Sokharev, V., Pakhomovsky, Y., Konopleva, N., Yakovenchuk, V., Bazai, A., Goryainov, P. \& Ivanyuk, G. in press: 3D mineralogical mapping of the Kovdor phoscorite-carbonatite complex (Russia). Mineralium Deposita. doi: 10.1007/s00126-015-0594-z.

Mitrofanov, F., Predovsky, A., Lyubtsov, V. \& Chikirev, I. 2004: The shore region of the Kola Peninsula: Structural zoning and petroleum potential. Geologiya i Geofizika 45, 151-160.

Mottaghy, D., Schellschmidt, R., Popov, Y., Clauser, C., Kukkonen, I., Nover, G., Milanovsky, S. \& Romushkevich, R. 2005: New heat flow data from the immediate vicinity of the Kola super-deep borehole: Vertical variation in heat flow confirmed and attributed to advection. Tectonophysics 401, 119-142.

Murrell, G.R. 2003: The long-term thermal evolution of central Fennoscandia, revealed by low-temperature thermochronometry. $\mathrm{PhD}$ 
thesis, Vrije Universiteit Amsterdam, 219 pp.

Murrell, G.R. \& Andriessen, P.A.M. 2004: Unravelling a long-term multi-event thermal record in the cratonic interior of southern Finland through apatite fission track thermochronology. Physics and Chemistry of the Earth, Parts A/B/C 29, 695-706.

Nassichuk, W. \& McIntyre, D. 1995: Cretaceous and Tertiary fossils discovered in kimberlites at Lac de Gras in the Slave Province, Northwest Territories. Geological Survey of Canada Current Research 1995, 109-114.

Nikishin, A.M., Ziegler, P.A., Stephenson, R.A., Cloetingh, S.A.P.L., Furne, A.V., Fokin, P.A., Ershov, A.V., Bolotov, S.N., Korotaev, M.V., Alekseev, A.S., Gorbachev, V.I., Shipilov, E.V., Lankreijer, A., Bembinova, E.Y. \& Shalimov, I.V. 1996: Late Precambrian to Triassic history of the East European Craton: dynamics of sedimentary basin evolution. Tectonophysics 268, 23-63.

Nivin, V.A. 2008a: Helium and argon isotopes in rocks and minerals of the Lovozero Alkaline Massif. Geochemistry International 46, $482-502$.

Nivin, V.A. 2008b: Helium and argon isotopes in rocks and minerals of the Lovozero Alkaline Massif. Geochemistry International 46, 482-502.

Nivin, V.A. 2011: Variations in the composition and origin of hydrocarbon gases from inclusions in minerals of the Khibiny and Lovozero plutons, Kola Peninsula, Russia. Geology of Ore Deposits $53,699-707$.

Öhman, T. \& Preeden, U. 2013: Shock metamorphic features in quartz grains from the Saarijärvi and Söderfjärden impact structures, Finland. Meteoritics \& Planetary Science 48, 955-975.

O'Leary, N., White, N., Tull, S., Bashilov, V., Kuprin, V., Natapov, L. \& Macdonald, D. 2004: Evolution of the Timan-Pechora and South Barents Sea basins. Geological Magazine 141, 141-160.

Olovyanishnikov, V.G., Roberts, D. \& Siedlecka, A. 1998: Tectonics and Sedimentation of the Meso- to Neoproterozoic Timan-Varanger Belt along the Northeastern Margin of Baltica. Polarforschung 68, 267-274.

Osadetz, K.G., Kohn, B.P., Feinstein, S. \& O'Sullivan, P.B. 2002: Thermal history of Canadian Williston basin from apatite fission-track thermochronology--implications for petroleum systems and geodynamic history. Tectonophysics 349, 221-249.

Paulamäki, S. \& Kuivamäki, A. 2006: Depositional history and tectonic regimes within and in the margins of the Fennoscandian Shield during the last 1300 million years. Geological Survey of Finland, Report 2006-43, 1-137.

Pekkala, Y. \& Yevzerov, V. 2000. Geology and prospects for exploitation of the kaolin deposits in the Eastern Fennoscandian Shield. Comprehensive Assessment of Nonmetalliferous Deposits: Proceedings of the Finnish-Soviet Symposium, Helsinki, Finland. 1, pp. 15-24.

Petrovsky, M., Savchenko, E. \& Kalachev, V.Y. 2012: Formation of eudialyte-bearing phonolite from Kontozero carbonatite paleovolcano, Kola Peninsula. Geology of Ore Deposits 54, 540-556.

Peulvast, J.-P., Claudino Sales, V., Bétard, F. \& Gunnell, Y. 2008: Low post-Cenomanian denudation depths across the Brazilian Northeast: Implications for long-term landscape evolution at a transform continental margin. Global and Planetary Change 62, 39-60.

Peulvast, J.-P., Bétard, F. \& Lageat, Y. 2009: Long-term landscape evolution and denudation rates in shield and platform areas: a morphostratigraphic approach. Geomorphologie 2, 95-108.

Redfield, T. \& Osmundsen, P. 2013: The long-term topographic response of a continent adjacent to a hyperextended margin: A case study from Scandinavia. Geological Society of America Bulletin 125, 184-200.

Roberts, D. 1995: Principal features of the structural geology of Rybachi and Sredni Peninsulas, and some comparisons with Varanger Peninsula. Norges geologiske undersøkelse Special Publication 7, 247-258.

Roberts, D. \& Lippard, S.J. 2005: Inferred Mesozoic faulting in Finnmark: current status and offshore links. Norges geologiske under- søkelse Bulletin 443, 55-60.

Roberts, D., Olesen, O. \& Karpuz, M.R. 1997: Seismo- and neotectonics in Finnmark, Kola Peninsula and the southern Barents Sea. Part 1: Geological and neotectonic framework. Tectonophysics 270, 1-13.

Rohrman, M. 1995: Thermal evolution of the Fennoscandian region from fission track thermochronology - An integrated approach. $\mathrm{PhD}$ thesis, Vrije Universiteit Amsterdam, 168 pp.

Shipilov, E.V. 2015: Late Mesozoic magmatism and Cenozoic tectonic deformations of the Barents Sea continental margin: Effect on hydrocarbon potential distribution. Geotectonics 49, 53-74.

Siedlecka, A. 1995: Neoproterozoic sedimentation on the Rybachi and Sredni Peninsulas and Kildin Island, NW Kola, Russia. Norges geologiske undersøkelse Bulletin 427, 52-55.

Siedlecka, A., Lyubtsov, V.V. \& Negrutsa, V.Z. 1995a: Correlation between Upper Proterozoic successions in the TanafjordenVarangerfjorden Region of Varanger Peninsula, northern Norway, and on Sredni Peninsula and Kildin Island in the northern coastal areas of Kola Peninsula in Russia. Norges geologiske undersøkelse Special Publication 7, 217-232.

Siedlecka, A., Negrutsa, V.Z. \& Pickering, K.T. 1995b: Upper Proterozoic turbidite system of the Rybachi Peninsula, northern Russia a possible stratigraphic counterpart of the Kongsfjord Submarine Fan of Varanger Peninsula, northern Norway. Norges geologiske undersøkelse Special Publication 7, 201-216.

Sindern, S., Zaitsev, A., Demény, A., Bell, K., Chakmouradian, A., Kramm, U., Moutte, J. \& Rukhlov, A. 2004: Mineralogy and geochemistry of silicate dyke rocks associated with carbonatites from the Khibina complex (Kola, Russia)-isotope constraints on genesis and small-scale mantle sources. Mineralogy and Petrology 80, 215-239.

Sokolov, S. 1981: Temperature variation in the production of alkaliultrabasic rocks with carbonatite intrusions. Geochemistry International 19, 159-166.

Stanley, J.R., Flowers, R.M. \& Bell, D.R. 2013: Kimberlite (U-Th)/He dating links surface erosion with lithospheric heating, thinning, and metasomatism in the southern African Plateau. Geology 41, 1243-1246.

Stasiuk, L.D., Sweet, A.R. \& Issler, D.R. 2006: Reconstruction of burial history of eroded Mesozoic strata using kimberlite shale xenoliths, volcaniclastic and crater facies, Northwest Territories, Canada. International Journal of Coal Geology 65, 129-145.

Sturkell, E. \& Lindström, M. 2004: The target peneplain of the Lockne impact. Meteoritics \& Planetary Science 39, 1721-1731.

Terekhov, E., Baluev, A. \& Przhiyalgovsky, E. 2012: Structural setting and geochemistry of Devonian dikes in the Kola Peninsula. Geotectonics 46, 69-84.

Tolstikhin, I., Kamensky, I., Nivin, V., Vetrin, V., Balaganskaya, E., Ikorsky, S., Gannibal, M., Kirnarsky, Y.M., Marty, B. \& Weiss, D. 1999: Low mantle plume component in 370 Ma old Kola ultrabasic-alkaline-carbonatite complexes: Evidences from rare gas isotopes and related trace elements. Russian Journal of Earth Sciences 1, 125-143.

Tolstikhin, I., Kamensky, I., Marty, B., Nivin, V., Vetrin, V., Balaganskaya, E., Ikorsky, S., Gannibal, M., Weiss, D. \& Verhulst, A. 2002: Rare gas isotopes and parent trace elements in ultrabasic-alkaline-carbonatite complexes, Kola Peninsula: identification of lower mantle plume component. Geochimica et Cosmochimica Acta 66, 881-901.

Vartiainen, H. \& Paarma, H. 1979: Geological characteristics of the Sokli carbonatite complex, Finland. Economic Geology 74, 12961306.

Veselovskiy, R.V., Arzamastsev, A.A., Demina, L.I., Travin, A.V. \& Botsyun, S.B. 2013: Paleomagnetism, geochronology, and magnetic mineralogy of Devonian dikes from the Kola alkaline province (NE Fennoscandian Shield). Izvestiya, Physics of the Solid Earth 49, 526-547.

Virovlyansky, G. 1975: Effect of the Depth of Emplacement and Erosion Level of the Khibiny and Lovozero Massifs on Their Apatite Ore Potential. Izv. AN SSSR, Ser. Geol 90-98. 
Vogt, C., Mottaghy, D., Rath, V., Marquart, G., Dijkshoorn, L., Wolf, A. \& Clauser, C. 2014: Vertical variation in heat flow on the Kola Peninsula: palaeoclimate or fluid flow? Geophysical Journal International 199, 829-843.

Williams, G.E. 2015: Hydrothermal alteration of Britain's oldest palaeosols: saddle dolomite and smectite at the Lewisian-Torridon Group (early Neoproterozoic) unconformity, NW Scotland. Scottish Journal of Geology 51, 63-68.

Wilson, M., Wijbrans, J., Fokin, P., Nikishin, A., Gorbachev, V. \& Nazarevich, B. 1999: 40Ar/39Ar dating, geochemistry and tectonic setting of Early Carboniferous dolerite sills in the Pechora Basin, foreland of the Polar Urals. Tectonophysics 313, 107-118.

Wolfe, A.P., Csank, A.Z., Reyes, A.V., McKellar, R.C., Tappert, R. \& Muehlenbachs, K. 2012: Pristine Early Eocene Wood Buried Deeply in Kimberlite from Northern Canada. PLOS ONE 7, e45537.

Zhuravlev, V. \& Shipilov, E. 2007: New data on the tectonics and structure of the sedimentary cover of the White Sea rift system. Doklady Earth Sciences 417, 1337-1341.

Zhuravlev, V.A. \& Shipilov, E.V. 2008: Structure of the basins of the White Sea rift systems. Oceanology 48, 114-122. 